\title{
Changes in nesting habitat of the saker falcon (Falco cherrug) influenced its diet composition and potentially threatened its population in Slovakia in the years 1976-2016
}

\author{
Zmena hniezdneho habitatu sokola rároha (Falco cherrug) mala vplyv na zloženie jeho \\ potravy a hrozby pre populáciu na Slovensku v rokoch 1976 - 2016
}

\author{
Jozef CHAVKO, Ján Obuch, Ján LIPTÁK, Roman SLOBODNÍK \& Michal BALÁž
}

\begin{abstract}
In the period between the years 1976 to 2016 we monitored the nesting site distribution of two populations of saker falcon (Falco cherrug) concentrated in the highlands and adjacent lowlands of western and eastern Slovakia. In western Slovakia we recorded nesting by 56 pairs and 514 nestings, and in eastern Slovakia we observed nesting by 32 pairs and 245 nestings. There were similar nesting success rates in both regions, with pairs producing on average 3.2 young in every successful nest. During the monitored period as a whole a total of 1,788 young saker falcons were raised. At the same time all the pairs gradually resettled in the lowlands, and in the new environment the nesting success rate significantly improved $(81.1 \%$ compared with $57.1 \%$ in the highlands). This change of nesting biotopes was caused by the impacts of intensive exploitation and environmentally inappropriate forest management, with the accompanying excessive disturbance of nesting birds, but at the same time the disappearance of ground squirrel (Spermophilus citellus) colonies led to a change in the food spectrum for the observed saker falcon pairs. We evaluated the falcons' feeding habits in western Slovakia between the years 1977 and 2016 (49 pairs; 1-17 pairs/year) and in eastern Slovakia between 2009 and 2016 (12 pairs; 1-3 pairs/year). Altogether 17,669 prey items were identified. From 1976 onwards mammals (Mammalia, 19.8\%, 24 species) became gradually less represented as a component in the falcons' diet compared with birds (Aves, 79.9\%, 58 species). In areas of western Slovakia we found stable and predominant proportions of domestic pigeons (Columba livia $\mathrm{f}$. domestica) ranging from $52 \%$ to $62 \%$. The proportion of pigeons was distinctly lower in eastern Slovakia (31.5\%), compensated for by larger shares of common vole (Microtus arvalis), common starling (Sturnus vulgaris), Eurasian magpie (Pica pica) and hooded crow (Corvus cornix). The common starling $(9.5 \%)$ was a significant prey species in the lowlands of western and eastern Slovakia alike. Mammals were mostly represented by common voles (9.8\%), European hamsters (Cricetus cricetus, 5.3\%), ground squirrels (2.1\%) and hares (Lepus europaeus, 1.6\%). Changes over time in the composition of falcons' prey were also evaluated over five periods in western Slovakia.
\end{abstract}

\begin{abstract}
Abstrakt: V období rokov 1976 až 2016 bola monitorovaná distribúcia hniezdisk dvoch populácii sokola rároha (Falco cherrug), sústredených v pohoriach a v pril’ahlých nížinách západného a východného Slovenska. Na západnom Slovensku sme zaznamenali hniezdenie 56 párov a 514 hniezdení, na východnom Slovensku sme sledovali hniezdenie 32 párov a 245 hniezdení. V oboch regiónoch bola podobná úspešnost' hniezdenia a páry produkovali priemerne 3.2 mlád’at’a na jedno úspešné hniezdo. Za celé sledované obdobie bolo vyvedených spolu 1788 mlád’at sokola rároha. Počas sledovaného obdobia sa všetky páry postupne presídlili na nížiny. V novom prostredí sa signifikantne zvýšila úspešnost' hniezdenia (81,1 \% oproti 57,1% v pohoriach). So zmenou hniezdnych biotopov, ktorá bola spôsobená vplyvom intenzívneho a environmentálne nevhodného lesohospodárskeho využivania a nadmerného vyrušovania, ako aj zánikom kolónií sysl’a pasienkového (Spermophilus citellus), došlo aj k zmene potravového spektra sledovaných párov sokolov rárohov. Vyhodnotená bola potrava sokola rároha zo západného Slovenska za roky 1977 až 2016 (49 párov; 1-17 p./year) a z východného Slovenska za roky 2009-2016 (12 párov; 1-3 p./year). Spolu bolo determinovaných 17669 kusov koristi. Cicavce (Mammalia, 19,8 \%, 24 druhov) boli po roku 1976 postupne stále menej zastúpenou zložkou potravy než vtáky (Aves, 79,9 \%, 58 druhov). V oblastiach západného Slovenska sme zistili stabilné a dominantné zastúpenie domácich holubov (Columba livia f. domestica) od 52 do 62 \%. Výrazne nižší bol podiel domácich holubov na východnom Slovensku (31,5 \%), kompenzovaný vy̌ším podielom hrabošov (Microtus arvalis), škorcov obyčajných (Sturnus vulgaris), strák obyčajných (Pica pica) a vrán popolavých (Corvus cornix). Významným druhom koristi v nížinách západného a východného Slovenska bol aj škorec $(9,5 \%)$. Z cicavcov boli najviac zastúpené hraboše pol’né (Microtus arvalis, 9,8 \%), chrčky (Cricetus cricetus, 5,3\%), sysle (2,1\%) a zajace (Lepus europaeus, 1,6 \%). Vyhodnotené boli aj časové zmeny v zastúpení koristi na západnom Slovensku v 5 periódach.
\end{abstract}

Key words: Falco cherrug, nesting distribution, food, management, threats, Slovakia 
Chavko J, Obuch J, Lipták J, Slobodník R \& Baláž M: Changes in nesting habitat of the saker falcon (Falco cherrug) influenced its diet composition and potentially threatened its population in Slovakia in the years 1976-2016

Jozef Chavko*, Roman Slobodník, Raptor Protection of Slovakia (RPS), Trhová 54, SK-841 01 Bratislava, Slovakia. *E-mail: chavko@dravce.sk.

Ján Obuch, Comenius University in Bratislava, Botanical Garden, SK-038 15 Blatnica, Slovakia.

Ján Lipták, Košice, Slovakia

Michal Baláž, Catholic University in Ružomberok, Faculty of Education, Hrabovská cesta 1, SK-03401 Ružomberok, Slovakia.

Acknowledgements: We hereby express our respect and gratitude to hundreds of deserving Czech and Slovak students, particularly Pavel Křŕžek, Pavel Sulan and Jaroslav Záhalka, the Malé Karpaty Mts. Protected Landscape Area Administration, the State Forests Administration and others who assisted with great commitment between 1991 and 1994 in protecting the nests of saker falcons especially from nest robbers, thus preventing the destruction of the population, thanks to which the continuity of the original gene pool was successfully preserved and nesting in the majority of original nesting sites was renewed. We thank Leonidas Prešinský for his help and cooperation in seeking out nests mainly in the Malé Karpaty Mts. area. Our special thanks go to the Slovakian Electricity Transmission Grid (SEPS), the East Slovakian Power Distribution Company and the West Slovakian Power Distribution Company, and various colleagues who supported us with their positive approach and practical help, especially Blanka Chavková, Slávka Siryová, Lucia Deutschová, Milka Martinská, Michal Noga, Boris Maderič, Andrej Vd'ačný, Marek Gális, Peter Rác, Luboš Vadel and Michal Hudec. For their help in monitoring nests in eastern Slovakia we thank Miloš Balla, Jozef Mihók and Bedřich Hájek. We are also grateful to our partners in cooperation: MME/BirdLife Hungary, the Presidium of the Slovakian Police Force, the Ministry for Environment of the Slovak Republic, and the Slovak State Nature Protection Agency. Last but not least we must thank the European Commission, which significantly supported the management measures for protection of the saker falcon through various projects within the LIFE Programme, namely: Protection of the saker falcon in the Carpathian basin (1/10/ 2006-30/9/2010); Protection of the saker falcon in north-east Bulgaria, Hungary, Romania and Slovakia (1/10/2010-30/9/2014), LIFE09 NAT/HU/000384; Energy in the Landscape - power lines and protection of priority bird species in the Natura 2000 areas (1.9.2014-31.12.2019, LIFE13 NAT/SK/001272).

\section{Introduction}

The saker falcon (Falco cherrug) inhabits the extensive steppe zone stretching from the Pannonian Basin eastwards through Moldavia, southern Ukraine, Russia and Kazachstan as far as the Asian steppes in southern Siberia, central Asia and western China. Outside the nesting period these falcons penetrate into western and southern Europe, the Middle East, western India and eastern China (Baumgart 1994). The Asian population reaches levels of 8,000-17,000 pairs, nesting in 10 to 13 countries (Dixon 2009). The European population (640720 pairs) makes up 7\% of the world's total (Kovács et al. 2014). With regard to Pannonia these falcons nest further north in Slovakia, to the west in southern Moravia (Beran et al. 2012) and Lower Austria (Frey \& Senn 1980, Zink et al. 2015) and to the south in Vojvodina, Serbia (Puzović 2008). The centre of the European population is in Ukraine and Hungary (Bagyura et al. 2004, Kovács et al. 2013).

In western Slovakia the last saker falcon pairs nested in their original nesting sites in the Strážovské vrchy Hills up until 1994, and in the Malé Karpaty Mts. until 2008. In the wetlands of the river Morava saker falcons nested up until 2001.

In eastern Slovakia the last pairs nested in their original nesting areas in the Slovakian Karst until 2002, in the Slovenské Rudohorie Mts. till 1981 and in the Slánske vrchy Hills until 2003.

The principal causes of the decline in saker falcon numbers in their distribution area are considered to be firstly the reduction in availability of key prey species due to human activity, and secondly the direct weakening of the population through nest robbery for falconry purposes. In some places this decline represents a threat to the very existence of these falcons (Horák 2000, Levin 2000, Moseikin 2000, Galushin et. al. 2001, Karyakin 2001, 2005, 2008, Levin et al. 2010, Štefanová \& Š́lek 2013, Stretesky et al. 2018). This negative trend has however been successfully stopped in several countries, mainly in Europe, thanks to preservation activities, and the species has exhibited population growth in recent years (see e.g. Beran et al. 2012, Gamauf 2012, Gamauf \& Dosedel 2013, Zink et al. 2015). On the other hand, in many countries with large falcon populations, the species continues to suffer decline (Kashkarov \& Lanovenko 2011, Galushin 2012, Rajković 2016).

The saker falcon is physically adapted to hunting animal prey on the ground and in the air, where it combines dynamic acceleration and flexible flight control. For this reason its preferred prey are small and mediumsized diurnal land-based rodents and lagomorphs, 
predominantly ground squirrels (Spermophilus citellus in Europe, $S$. dauricus, $S$. erythrogenys, $S$. leptodactylus, S. relictus, S. pygmaeus, S. major, S. fulvus and Urocitellus undulatus in Asia); hamsters (Cricetus cricetus in Europe, Ellobius talpinus in Asia), voles (Microtus arvalis mainly in Europe, M. brandtii, M. gregalis, M. mongolicus in Asia), gerbils (Meriones meridianus, M. unguiculatus, Rhombomys opimus) and hares, but also pikas (Ochotona curzoniae, O. daurica, O. melanostomata), marmots (Marmota sibirica, $M$. bobak) in mountain areas, and wood and field mice (Apodemus sylvaticus), rats, jerboas (Alactaga sibirica) and steppe lemmings (Lagurus lagurus). The proportion of mammals in the prey, while usually the principal diet component everywhere, naturally depends on their availability, so it differs seasonally, annually and regionally (Kovács et al. 2014). Birds are generally less represented as the primary food, but they can make up from 30 to $60 \%$ of the falcons' diet during the nesting season (Kovács et al. 2014). Older data on the saker falcon diet throughout its distribution area were summarized by Baumgart (1980). In the Pannonian Lowlands the main prey in the past used to be medium-sized rodents such as ground squirrels and hamsters (Baumgart 1980). Obuch \& Chavko (1997) studied the falcons' diet in western Slovakia especially in the period from 1978 to 1995 , when the majority of nests was still located in the highlands (Chavko 2002a). Chavko \& Deutschová (2012) and Chavko et al. (2014) then reported updated information about the species' diet in Slovakia. The situation has changed in Slovakia compared to the state found in those published works, and we have comprehensively reworked the data covering the whole monitored time period, focusing on finding the missing correlations between changes in nesting habitat, food sources and population threats. In addition we have supplemented data on trends in the falcon population and diet in eastern Slovakia. In this way we have potentially achieved our aim of documenting the development and composition of the saker falcon diet within the whole nesting population in Slovakia during the last forty years.

In Hungary the diet of this species has been studied for example by Bagyura et al (1994) and later also by Balázs (2008). The typical feature of these falcons is kleptoparasitism (see e.g. Pfeffer 1994, Braun \& Lederer 1996, Puzović 2008).

The principal aim of this study was to describe the change in the saker falcons' preferred nesting habitat in two geographical areas of western and eastern Slovakia in the period between 1979 and 2016, namely their shift from the hills down into agricultural country. We compare the success rates of pairs nesting in trees and rocky outcrops with those nesting in boxes and on platforms attached to power line pylons in agricultural areas. We also track the range of prey hunted during the last $40+$ years in the studied nesting sites of the falcon poppulation around Slovakia, and compare their diet compositions in several orographic regions in this country. We additionally focus on monitoring and identifying threats to the falcon population, and on directly implementing management measures for their mitigation.

\section{Materials and methods}

In the period from 1976 till 2016 we monitored the disribution of nesting sites of two populations of saker falcon in Slovakia, concentrated in the hills and adjacent lowlands in the western and eastern parts of this country. In western Slovakia we monitored the nesting of 56 pairs, and in the period 1976 to 2016 we recorded a total of 514 nestings.

In eastern Slovakia in the period 1979 to 2016 we monitored the nesting of 32 pairs, and in the monitored period we recorded a total of 245 nestings.

We evaluated the results of collections of saker falcon food remains between 1978 and 2016 taken from 49 pairs in western Slovakia (314 annual collections) and in the years 2009, 2010, 2015 and 2016 from 9 pairs in eastern Slovakia (15 annual collections).

Monitoring of nesting was performed using the direct observation method. In the autumn and winter seasons we mapped the nests in the selected upland areas. During spring we then verified their occupancy by direct observation and based on the falcons' behaviour (courting flights).

Since 1991 we have been working in cooperation with the Slovakian Power Transmission Grid (SEPS) to progressively create new nesting opportunities for falcons in the form of boxes fitted to pylons in in selected parts of prey-hunting areas and known wintering sites.

We verified nesting and the occupancy of nests in trees and on electricity pylons by means of direct observation of all known nests and installed nesting-boxes. In addition we also checked all relevant historical nesting sites, even if previously abandoned, to verify whether or not they had been newly reoccupied. We checked nest occupancy at least four times a year, and we checked every occupied nest or box physically by climbing up at least twice in every season, the first time in order to ring the young birds and the second time after the young 
birds flew from the nest in order to collect food remains. We paid special attention to finds of particular prey species indicating that the falcons also brought remnants of found carrion to their nests. Data obtained prior to 1975 from two abandoned nests in rocky outcrops, which have been included in the comparison of changes over time, were taken from our previous study (Obuch \& Chavko 1997). In the same way for the purposes of this work we have made use of data from the study by Chavko \& Deutschová (2012). Their study presents only partial data with no details of saker falcons' diet in eastern Slovakia, and with no reference to the comprehensive comparison over time of the diets of individual pairs in various orographic areas.

Food remains were collected in eight orographic areas around Slovakia (Malé Karpaty Mts., Burda Mts., Borská nížina Lowlands, Podunajská rovina Plain, Trnavská pahorkatina Uplands, Nitrianska pahorkatina Uplands, Košická kotlina Basin and Východoslovenská rovina East Slovakian Plain). Nest and nesting-boxes were cleared annually of all prey remains, so that samples taken in the following year were not spoilt with admixtures of remnants from the previous period. The osteological material obtained was treated with $5 \% \mathrm{Na}-$ $\mathrm{OH}$ solution, then washed in water and prepared for identification. This was done using the jaws of mammals (maxilla and mandibula), for birds also with the humerus, metacarpus and tarsometatarsus, and particular body parts for lower vertebrates and invertebrates. Proportions of prey species in individual collections were established on the basis of the most numerous identified bones of particular prey species. In the case of birds the most frequently identified bone was the humerus. Collections of food remnants from nesting-boxes were more comprehensive than those from tree nests, where part of the food remnants had always fallen into the vegetation on the ground. The authors estimate that during their monitoring of nests in the period from 1979 onwards they had around $95-97 \%$ of all nesting pairs in Slovakia under constant observation, and food samples were taken from $87.5 \%$ of all monitored pairs in western and $28 \%$ of pairs in eastern Slovakia.

\section{D a $\mathrm{t}$ a a n a 1 y s i s}

Data on the saker falcon diet were processed separately for each of the orographic areas, and subsequently they were compared with each other (seven groups, as the areas of the Malé Karpaty Mts. and Burda Mts. were evaluated together as one group). With regard to diet changes over time, five time periods were set up: prior to $1975,1977-1989,1990-1999,2000-2009$ and $2010-$ 2016.

The results of the diet composition research were evaluated using the calculation method of marked differences from the mean (MDFM, Obuch 2001). They are presented in tables in which the ranking of prey species and samples is set up so that the diagnostic species with positive deviations from the mean create closed blocks. More numerous species with no clear deviations, i.e. evenly represented in all compared samples, are placed below the dotted line and ranked from the most to the least numerous. The diversity index H' was calculated using the formula of Shannon \& Weaver (1949). The Zber database program (Šipöcz 2004) was used in compiling the tables.

The predominance of species in the food spectrum in particular years (seasons) was calculated based on the work of Losos et al. (1985), i.e. as the percentage representation of individual species in the given year (season) in the monitored nests.

In order to visualize the differences between food remnants we used indirect gradient analysis (principal component analysis, PCA), since the gradient length found with detrended correspondence analysis (DCA) had a value of 1.166 . We used relative numbers (predominance) of identified prey species as our input data at the level of individual time periods and/or orographic areas. Data were processed for 47 prey species, seven orographic areas and/or five time periods. For PCA analysis we used square root transformation of the species data. In the scaling we focused on inter-species correlations. The data were centred within the samples (in our case: locations, years). The analyses were carried out using CANOCO 4.5 software (Microcomputer Power, USA; TerBraak \& Šmilauer 2002).

The nesting success rate was set as the ratio of successful nests to the total number of monitored nests in particular years, and it was tested using the $\chi^{2}$ test. Analysis was performed using the Statistica 7 program (Statsoft, USA).

\section{Results \\ P o pulation trend and ne sting $\mathrm{s} \mathrm{u} \mathrm{c} \mathrm{c} \mathrm{e} \mathrm{s} \mathrm{s} \mathrm{r} \mathrm{a} \mathrm{t} \mathrm{e}$}

In the period 1976-2016 nesting by 88 pairs of saker falcons was recorded in Slovakia (altogether 759 nestings). Of these in that period 56 pairs nested in southwestern Slovakia and 32 pairs in south-eastern Slovakia. In western Slovakia 196 nestings were recorded in the hills and wetland forests and 318 nestings in the 

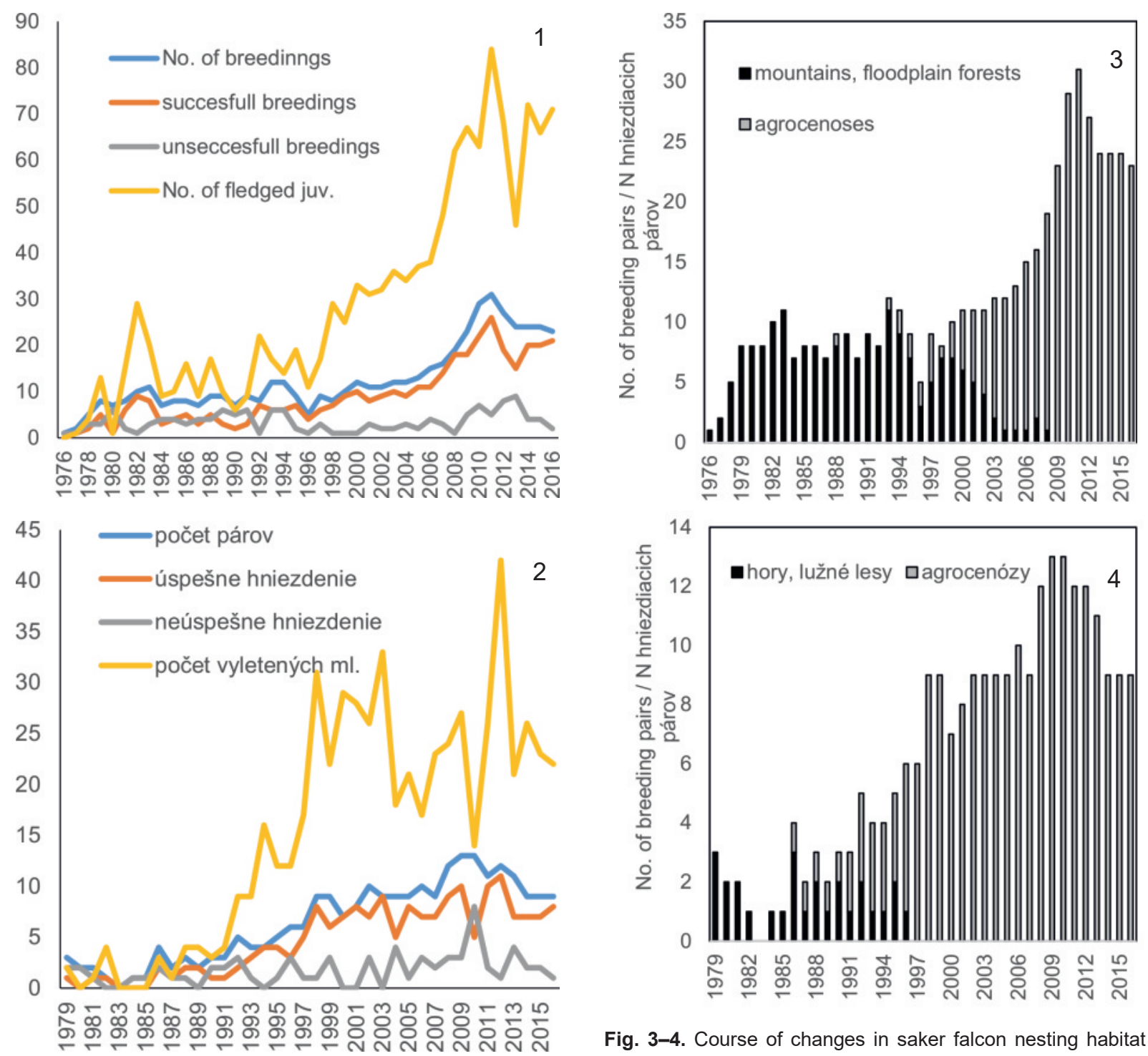

Fig. 1-2. Development trend in saker falcon population in western Slovakia in 1976-2016 (1) and in eastern Slovakia in 1979-2016 (2).

Obr. 1 - 2. Trend vývoja západoslovenskej populácie sokola rároha v období rokov 1976 - 2016 (1) a východoslovenskej populácie v období rokov 1979 - 2016 (2).

lowlands on agricultural land (Fig. 1). In eastern Slovakia 27 nestings were monitored in the hills and 218 in lowland agricultural areas in the period 19792016 (Fig. 2).

During the monitored period a change in the saker falcons' preference for nesting habitat was recorded. While at the beginning of the monitored period all pairs

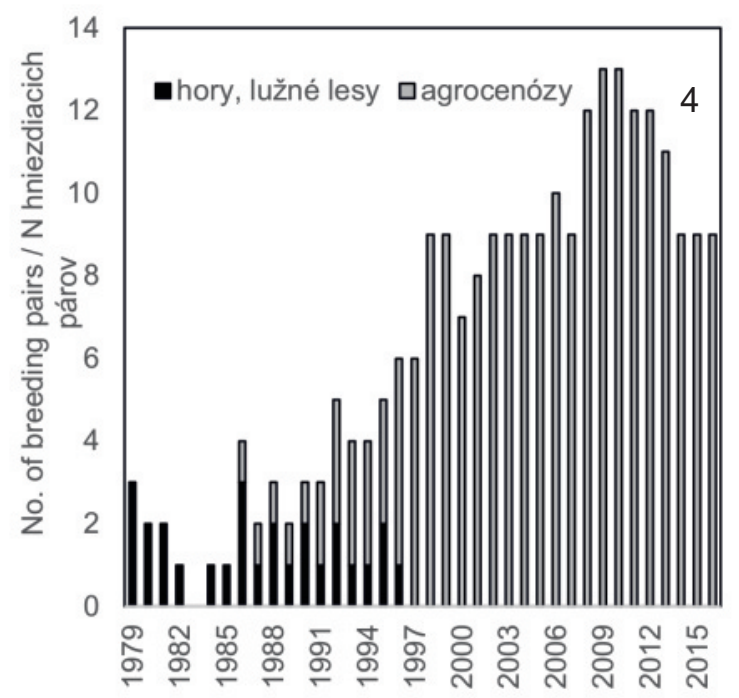

Fig. 3-4. Course of changes in saker falcon nesting habitat in western Slovakia in 1976-2016 (3) and in eastern Slovakia in 1979-2016 (4).

Obr. 3 - 4. Priebeh zmien hniezdneho habitatu sokola rároha na západnom Slovensku v období rokov 1976 - 2016 (3) a na východnom Slovensku Slovensku v rokoch 1979 - 2016 (4).

in both western and eastern Slovakia nested in upland forest environments, over time they gradually resettled in agricultural country, and they started using boxes and platforms installed on power line pylons for their nesting (Figs. 3, 4, 5a, 5b). We recorded the first nesting in farmland in western Slovakia in 1988, the falcons using an old crows' nest on a pylon, and we assume that the 

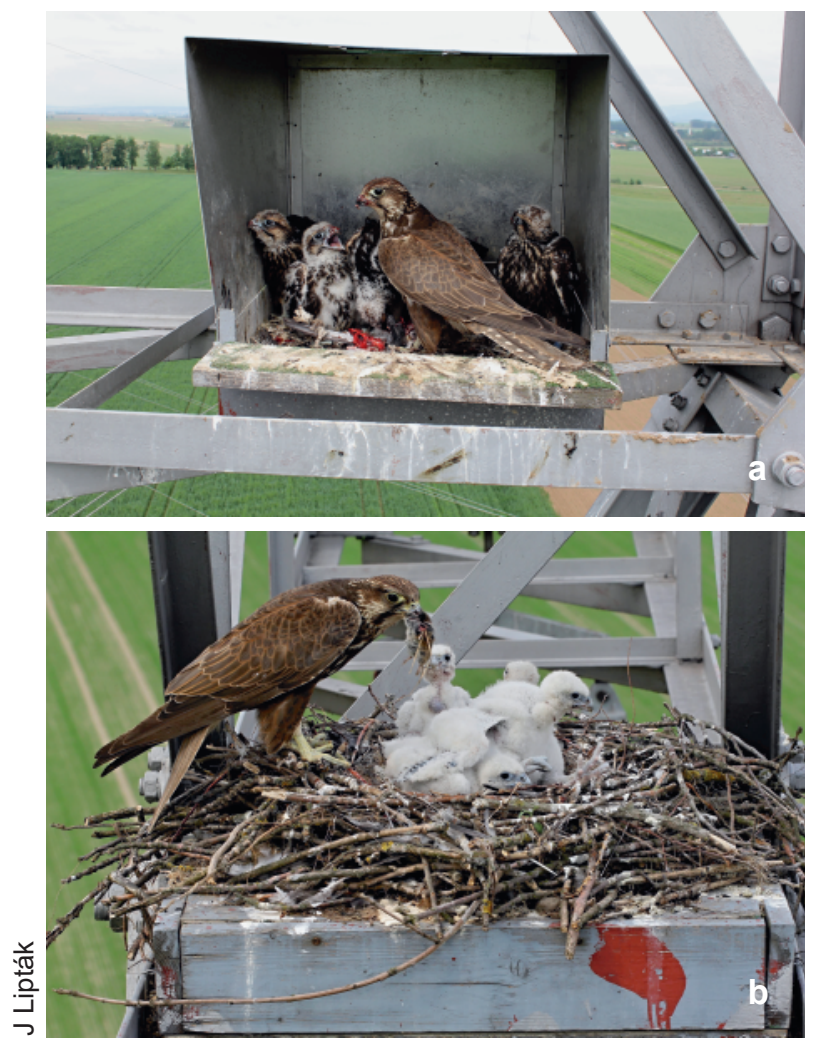

Fig. 5. Nesting box (a) and nesting platform (b) on a power line pylon occupied by saker falcons. This kind of nesting is currently most frequent throughout agricultural countryside in Slovakia.

Obr. 5. Hniezdna búdka (a) a hniezdna podložka (b) na stožiari elektrického vedenia obsadená sokolom rárohom. Tento typ hniezdenia je $v$ dnešnej dobe $v$ pol'nohospodárskej krajine Slovenska najčastejší.

reason for their absence up to that point was the distinct lack of natural nesting opportunities in the intensivelycultivated agricultural countryside. Nesting by the first pair in farmland was recorded in the Košice Basin (south-eastern Slovakia) as early as 1986, however. Since 2002 in western Slovakia and since 1991 in the east, the majority of pairs have nested in the changed biotope of agricultural land, and the last instances of active nesting in upland areas were recorded in the Slánske vrchy Hills (eastern Slovakia) in 1996 and in the Malé Karpaty Mts. (western Slovakia) in 2008.

As a result of the resettlement of the monitored saker falcon pairs from the hills and wetland forests into agricultural countryside, there have been changes in the borders of their nesting areas. The dimensions of that area in western Slovakia have however remained almost unchanged: the original area extended over 355,247 hectares while the area occupied by pairs in the lowlands was 395,692 ha. In eastern Slovakia the current extent of the nesting area in agricultural country has become slightly smaller than the original one in the hills: 186,426 ha vs. 123,419 ha (Fig. 6,7 ).

During the whole study period a total of 1,788 saker falcon young were raised in all types of nest in both monitored regions. Significantly higher nesting success rates were found for falcons nesting in agricultural country compared with the nesting sites in the hills, and this is true for both studied geographical areas (eastern as well as western Slovakia), and moreover when the data were combined $\left(\chi^{2}=37.94, \mathrm{P}<0.001\right)$. In agricultural country the average success rate was $81.1 \%$ for all nests with 2.7 young raised per nest overall, or 3.3 young for each successful nest. In the hills the average was 1.7 young flying per nest overall, or 2.9 young from each successful nest, the proportion of successful nests being just $57.1 \%$ overall.

In the monitored period the nesting success rate for saker falcons nesting in boxes on pylons was significantly higher than for pairs nesting in the past in natural nests in upland areas (81.1\% compared to $57.1 \%$ respectively), and pairs nesting in boxes were also more productive, with a higher average number of raised young for each successful nest (3.3 compared to 2.9 young for each successful nest respectively). The two monitored populations, although 250 to $300 \mathrm{~km}$ distant from each other, displayed almost identical long-term average success rates. The west Slovakian population had average success rates of 2.4 young per nest overall and 3.2 young per successful nest, and in the east Slovakian population the figures were 2.3 and 3.2 young per nest respectively (Appendix 1,2).

F o o d

From all the saker falcon pairs we monitored we obtained samples of 17,669 prey items from 61 different nests (45 in farmland, 16 in uplands and wetland woods). Mammals (Mammalia, 19.8\%, 24 species) became from 1980 onwards a progressively less important component of the falcons' diet compared to birds (Aves, $79.9 \%, 58$ species). There was an occasional occurrence of amphibians (Amphibia, 3 species: Rana cf. esculenta, Bufo bufo, Pelobates fuscus), reptiles (Reptilia, 1 species: Lacerta agilis) and fish (Pisces, 1 unidentified instance); invertebrates were represented mainly by Coleoptera $(0.1 \%)$.

The most frequently hunted prey species was the domestic pigeon (Columba livia f. domestica), which made 
Fig. 6-7. Distribution of saker falcon nesting sites and territorial changes in nesting distribution in western Slovakia (19762016) (6) and in eastern Slovakia (19792016) (7). Blue colour indicates the original area of nesting distribution up until 2008 (6) and 1996 (7), and yellow indicates the area of nesting distribution 2002-2016 (6) and 1991-2016 (7). Nesting sites where no sample collection took place are marked in red.

Obr. 6 - 7. Distribúcia hniezdisk sokola rároha a územné zmeny hniezdneho rozšírenia na západnom Slovensku (1976 - 2016) (6) a na východnom Slovensku (1979 - 2016). Modrou je vyznačený pôvodný areál hniezdneho rozšírenia do 2008 (6) a 1996 (7) a žltou je vyznačený areál hniezdneho rozšírenia v období 2002 2016 (6) a 1991 - 2016 (7). Červenou farbou sú vyznačené hniezdiská, kde nebol vykonávaný zber vzoriek.
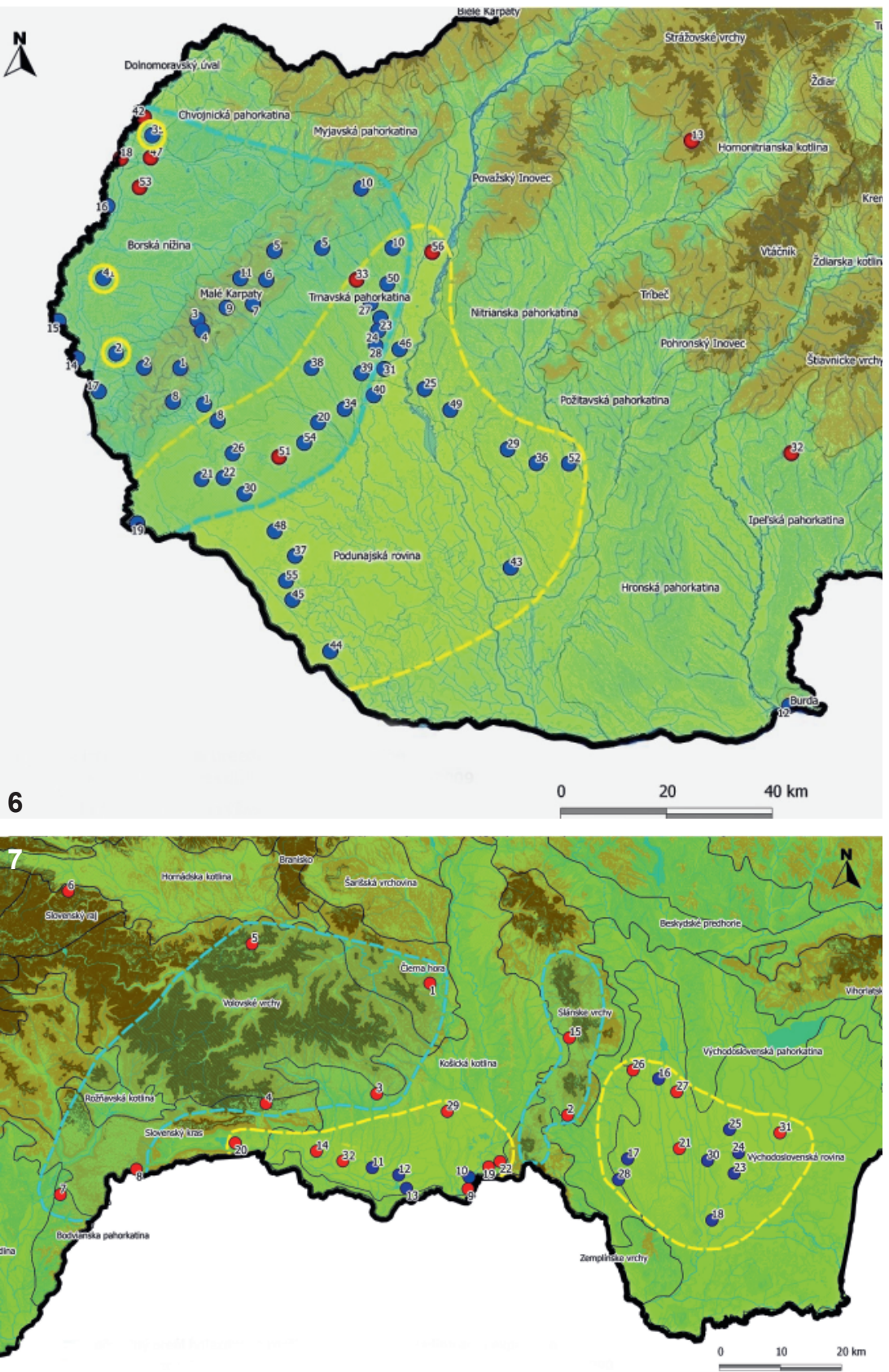

up on average $57 \%$ of the food spectrum throughout the monitored period. The next most frequently hunted prey were starlings, common voles and hamsters (Tab. 1).

Comparing the prey compositions in the five separate time periods, we were able to plot the changes connected with resettlement of the saker falcon populations from the hills down into open countryside. The indirect ordination diagram produced from PCA differentiates the food spectrum found up until 1975 from the prey remnants collected in the later periods (Fig. 8). The period prior to 1975 was characterized by a relatively low share of domestic pigeon (16.8\%) and a higher proportion of wild pigeons Columba oenas and C. palumbus. Before 1975 there was considerably greater diversity of prey species $\left(\mathrm{H}^{\star}=2.45\right)$ compared to the last forty years, during which the diversity index varied 
Chavko J, Obuch J, Lipták J, Slobodník R \& Baláž M: Changes in nesting habitat of the saker falcon (Falco cherrug) influenced its diet composition and potentially threatened its population in Slovakia in the years 1976-2016

Tab 1. Comparison of saker falcon diet components in selected orographic areas of Slovakia. Numerical data in the table are given in absolute values, and positive and negative deviations (e.g 1+, 2+, 1-, 2- ) are marked deviations from the mean (MDFM, Obuch 2001) for the species in these samples (see Methods).

Tab. 1. Porovnanie potravy sokola rároha v orografických celkoch Slovenska. Číselné hodnoty $v$ tabul'ke sú uvedené $v$ absolútnych hodnotách, kladné a záporné odchýlky (1+, 2+, 1-, 2- a podobne) sú výrazné odchýlky od priemeru (MDFM, Obuch 2001) druhov vo vzorkách (pozri Metodiku).

\begin{tabular}{|c|c|c|c|c|c|c|c|c|c|}
\hline area / územie & MK & BN & PdR & $\operatorname{TrP}$ & NP & KK & VsR & & \\
\hline taxa / taxón & 5 & 1 & 2 & 3 & 4 & 6 & 7 & $\Sigma$ & $\%$ \\
\hline Spermophilus citellus & $2+235$ & 19 & 106 & $5-$ & 3- & $1-$ & 3- & 366 & 2.70 \\
\hline Sciurus vulgaris & $1+10$ & & & & & & & 10 & 0.06 \\
\hline Perdix perdix & $1+83$ & 13 & 77 & 73 & $1-\quad 11$ & $1-$ & $2-$ & 261 & 1.48 \\
\hline Vanellus vanellus & $1+43$ & 4 & 30 & 12 & 9 & 1 & 14 & 113 & 0.64 \\
\hline Streptopelia turtur & $1+46$ & $1-$ & 21 & $1-$ & $1-$ & & 12 & 90 & 0.51 \\
\hline Turdus philomelos & $1+18$ & 6 & $2-$ & $1-$ & 5 & 1 & 1 & 32 & 0.18 \\
\hline Coccothraustes coccothr. & $1+10$ & 1 & 1 & & & & 1 & 13 & 0.07 \\
\hline Corvus frugilegus & $1+7$ & & 2 & & & 1 & 1 & 11 & 0.06 \\
\hline Phasianus colchicus & $1-\quad 49$ & $1+57$ & $1+183$ & 128 & 44 & $1-$ & 40 & 504 & 2.85 \\
\hline Chroicocephalus ridibundus & $1-\quad 22$ & $1+31$ & $1+101$ & 23 & $2-$ & $1-$ & $2-$ & 181 & 1.20 \\
\hline Columba oenas & 87 & 25 & $1+178$ & 78 & 45 & $1+34$ & 25 & 472 & 2.67 \\
\hline Columba palumbus & $1-\quad 29$ & 11 & $1+140$ & $1+110$ & $1-\quad 18$ & $1-4$ & 16 & 328 & 1.86 \\
\hline Cricetus cricetus & $1-144$ & 3- & $1-167$ & $1+404$ & 117 & 21 & 72 & 929 & 5.26 \\
\hline Lepus europaeus & $1-\quad 28$ & 13 & 79 & $1+86$ & $1+59$ & $1-\quad 2$ & 10 & 277 & 1.57 \\
\hline Nyctalus noctula & $1-$ & 1 & 10 & $1+$ & $1+12$ & 1 & 2 & 53 & 0.30 \\
\hline Talpa europaea & $1-$ & 1 & 6 & 7 & $1+16$ & 2 & 6 & 39 & 0.22 \\
\hline Mus cf. musculus & & & 2 & 1 & $1+7$ & 1 & 2 & 13 & 0.07 \\
\hline Sturnus vulgaris & 422 & $1+166$ & $1-300$ & 176 & $1+271$ & $1+74$ & $1+263$ & 1,672 & 9.46 \\
\hline Pica pica & $2-\quad 2.7$ & $2-\quad 0$ & 2.8 & 51 & $1-\quad 5$ & $2+34$ & $2+71$ & 176 & 1.00 \\
\hline Microtus arvalis & $2-151$ & 40 & $1-244$ & $1+548$ & 215 & $1+113$ & $2+425$ & 1,736 & 9.83 \\
\hline Corvus cornix & 3 & & $1-\quad 0$ & $1-\quad 0$ & 1 & & $2+\quad 13$ & 17 & 0.10 \\
\hline Alauda arvensis & 13 & 2 & 12 & 10 & 7 & 4 & $1+10$ & 58 & 0.33 \\
\hline Coleoptera sp. & $1-$ & & $1-$ & $1-$ & & 4 & $2+21$ & 25 & 0.14 \\
\hline Lacerta agilis & & 1 & 3 & $1-$ & 1 & & $2+\quad 12$ & 17 & 0.10 \\
\hline Apodemus agrarius & & & & & & & $1+$ & 5 & 0.03 \\
\hline Garrulus glandarius & 9 & & $1-$ & 12 & 8 & 3 & 4 & 37 & 0.21 \\
\hline Columba livia dom. (n) & 2,486 & 609 & 2,684 & 2,378 & 1,019 & 1- 205 & 1- 395 & 9,776 & 55.33 \\
\hline$\%$ & 62.10 & 58.67 & 60.10 & 56.48 & 52.72 & 38.83 & 26.49 & & \\
\hline Coturnix coturnix & 14 & 5 & 27 & 18 & 5 & 1 & 7 & 77 & 0.44 \\
\hline Streptopelia decaocto & 11 & 3 & 14 & 19 & 13 & 2 & 7 & 69 & 0.39 \\
\hline Turdus merula & 11 & 4 & 4 & 5 & 4 & & 3 & 31 & 0.18 \\
\hline Passer montanus & 3 & & 6 & 3 & 5 & 1 & 5 & 23 & 0.13 \\
\hline Passer domesticus & 1 & & 4 & 4 & 3 & 2 & 3 & 17 & 0.10 \\
\hline Apodemus flavicollis & 1 & 1 & 3 & 2 & & 2 & 5 & 14 & 0.08 \\
\hline Coloelus monedula & 1 & 1 & 3 & 3 & 1 & & 2 & 11 & 0.06 \\
\hline Rattus norvegicus & 3 & & 2 & 2 & & & 3 & 10 & 0.06 \\
\hline Falco tinnunculus & 1 & 1 & 5 & 1 & 1 & & & 9 & 0.05 \\
\hline Asio otus & 1 & & 1 & 4 & 1 & & 1 & 8 & 0.05 \\
\hline Turdus pilaris & 2 & & 2 & 1 & & 1 & 2 & 8 & 0.05 \\
\hline Apodemus sylvaticus & 2 & & 3 & & 2 & & & 7 & 0.04 \\
\hline Apodemus microps & & & & 1 & 1 & 1 & 4 & 7 & 0.04 \\
\hline Mammalia, 24 species & 1- 583 & 2- 82 & 1- 631 & $1+1,077$ & 435 & $1+148$ & $1+541$ & 3,497 & 19.79 \\
\hline Aves, minim. 58 species & 3,420 & 954 & 3,832 & 3,132 & 1,497 & 376 & 1- 913 & 14,124 & 79.94 \\
\hline Amphibia, Reptilia, Pisces & 1- $\quad 0$ & 2 & 3 & 1 & 1 & 0 & $2+\quad 14$ & 21 & 0.12 \\
\hline Evertebrata & 1- $\quad 0$ & 0 & 1- & 1- & 0 & 4 & $2+\quad 23$ & 27 & 0.15 \\
\hline $\bar{\Sigma}$ & 4,003 & 1,038 & 4,466 & 4,210 & 1,933 & 528 & 1,491 & 17,669 & 100.00 \\
\hline Diversity Index H' & 1.64 & 1.61 & 1.74 & 1.68 & 1.78 & 1.95 & 2.20 & 1.86 & \\
\hline
\end{tabular}

Area no. I územie: 5, MK - Malé Karpaty Mts. + Burda Mts., 1, BN - Borská nížina Lowlands, 2, PdR - Podunajská rovina Plain, 3, TrP - Trnavská pahorkatina Uplands, 4, NP - Nitrianska pahorkatina Uplands, 6, KK - Košická kotlina Basin, 7, VsR Východoslovenská rovina Plain.

Other species (Area no.-number) / ostatné druhy (územie č. -počet):

Sorex araneus $(5-1 ; 2-3 ; 6-1 ; 7-1)$, Sorex minutus (7-1), Crocidura leucodon (2-2; 4-1; 7-1), Crocidura suaveolens (2-1; 7-1), 
Fig. 8. Ordination diagram of PCA analyses. relative proportions of species identified in the saker falcon diet and their distribution in the individual orographic areas (MK - Malé Karpaty Mts. + Burda Mts., BN - Borská nížina Lowlands, PdR - Podunajská rovina Plain, TrP - Trnavská pahorkatina Uplands, NP - Nitrianska pahorkatina Uplands, KK - Košická kotlina Basin, VsR Východoslovenská rovina Plain.)

Obr. 8. Ordinačný diagram PCA analýzy - vztahy medzi druhmi zaznamenaných $v$ potrave sokola rároha a ich distribúciou $v$ jednotlivých orografických celkoch (MK - Malé Karpaty + Burda Mts., BN - Borská nížina, PdR - Podunajská rovina, TrP Trnavská pahorkatina, NP - Nitrianska pahorkatina, KK - Košická kotlina, VsR - Východoslovenská rovina.)

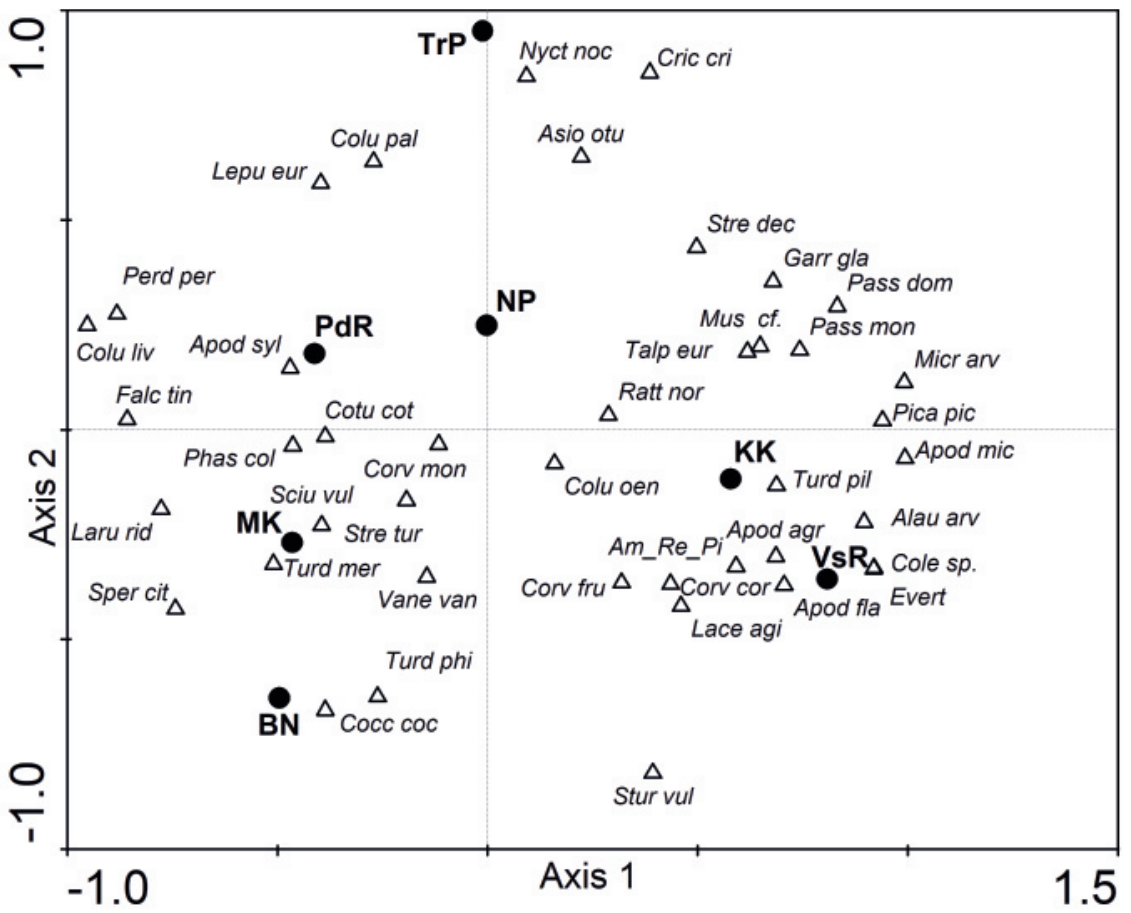

in the range from 1.45 to 1.80 with indirect dependence on the share of domestic pigeon from $66.5 \%$ to $55.0 \%$. The share of domestic pigeons culminated during the decade 1990-1999, and then gradually declined to a minimum in the period 2010-2016 (Tab. 2).

The shift of nesting pairs down into agricultural country is associated with changing preferences among the falcons for certain mammal species, whose share in the falcons' diet then rose (e.g. Microtus arvalis, Lepus europaeus, Cricetus cricetus, Nyctalus noctula and Talpa europaea), and similarly the representation of the common pheasant Phasianus colchicus also increased during the decade 2000-2009. In contrast, while the saker falcons nested up in the hills, the species more often found in their diet were Sciurus vulgaris, Sturnus vulgaris and Turdus philomelos. During the first periods of monitored nesting, 1977-1989 and 19901999, the proportion of species Spermophilus citellus, Streptopelia turtur, Perdix perdix and Vanellus vanellus gradually declined, while the species Coturnix coturnix, Alauda arvensis, Garrulus glandarius and Turdus merula maintained similar relative proportions throughout the time periods being compared (Tab. 2).

We also found differences in diet composition among the saker falcons nesting in the separate orographic areas of Slovakia. Comparing their food in the individual time periods, we found a difference in the analyzed samples between nests in the orographic areas of western and eastern Slovakia. Despite the clearly highest proportion of the domestic pigeon in the falcons' diet in all types of countryside, in western Slovakia they hunted a roughly twofold greater number of domestic

Eptesicus serotinus (5-1), Muscardinus avellanarius (5-1), Apodemus sp. (3-1), Arvicola amphibius (1-2; 2-1; 3-1; 6-1), Terricola subterraneus $(5-1 ; 7-1)$, Vulpes vulpes $(2-1)$, Mustela erminea (7-1), Capreolus capreolus (5-1; 1-1; 2-1; 4-1), Artiodactyla sp. (6-1; 7-1), Anas platyrhynchos (1-1; 2-2), Anas crecca (2-2), Gallus gallus dom. (2-1; 6-1), Rallus aquaticus (2-1), Crex crex (2-2; 4-1; 7-1), Pluvialis apricaria (5-1), Tringa totanus (5-1), Philomachus pugnax (2-1; 3-1), Scolopax rusticola (5-1; 21), Larus canus (5-2), Larus michahellis (3-2), Tyto alba (4-1), Asio flammeus (4-1), Apus apus (5-1; 3-1; 6-1), Melopsittacus undulatus (5-1; 2-2; 3-1; 4-1), Psittacidae (2-2; 3-1; 4-3), Dendrocopos major (5-1), Dendrocopos sp. (5-1), Lullula arborea (3-4), Galerida cristata (5-2; 7-1), Motacilla alba (7-1), Bombycilla garrulus (5-1), Lanius collurio (4-2), Turdus iliacus (3-1), Turdus viscivorus $(5-2 ; 1-1 ; 2-1)$, Parus major $(5-2 ; 7-1)$, Emberiza citrinella (5-1), Fringilla coelebs $(1-1 ; 2-1 ; 4-1 ; 6-1)$, Carduelis carduelis $(2-1 ; 7-2)$, Carduelis spinus $(2-2 ; 6-1 ; 7-1)$, Carduelis cannabina $(3-1 ; 7-1)$, Carduelis chloris (5-1; 7-1), Pyrrhula pyrrhula (5-1), Loxia curvirostra (5-1), Passeriformes (5-21; 1-11; 2-7; 3-2; 4-4; 7-3), Aves (3-1), Aves juv. (2-2; 4-2), Pelobates fuscus (7-1), Bufo bufo (7-1), Pelophylax cf. esculentus (3-1), Pisces (1-1), Gryllotalpa gryllotalpa (7-2). 
Chavko J, Obuch J, Lipták J, Slobodník R \& Baláž M: Changes in nesting habitat of the saker falcon (Falco cherrug) influenced its diet composition and potentially threatened its population in Slovakia in the years 1976-2016

Tab. 2. Temporal changes in the diet of saker falcon in western Slovakia. Numerical data in the table are given in absolute values, and positive and negative deviations (e.g 1+, 2+, 1-, 2- ) are marked deviations from the mean (MDFM, Obuch 2001) for the species in these samples (see Methods).

Tab. 2. Časové zmeny $v$ zastúpení koristi sokola rároha na západnom Slovensku. Číselné hodnoty $v$ tabul'ke sú uvedené $\checkmark$ absolútnych hodnotách, kladné a záporné odchýlky (1+, 2+, 1-, 2- a podobne) sú výrazné odchýlky od priemeru (MDFM, Obuch 2001) druhov vo vzorkách (pozri Metodiku).

\begin{tabular}{|c|c|c|c|c|c|c|c|c|}
\hline taxa / taxón // years / roky & $<1975$ & & $77-89$ & $90-99$ & $00-09$ & $10-16$ & $\Sigma$ & $\%$ \\
\hline Columba oenas & $2+$ & $2-$ & 4 & 11 & 151 & 242 & 476 & 2.97 \\
\hline Columba palumbus & $1+$ & $2-$ & 4 & $1-$ & 98 & 179 & 314 & 1.96 \\
\hline Streptopelia turtur & $3+$ & $2+$ & 34 & $1-$ & 25 & 17 & 138 & 0.86 \\
\hline Perdix perdix & 106 & $1+$ & 49 & 18 & 106 & 83 & 362 & 2.26 \\
\hline Vanellus vanellus & $1+$ & $2+$ & 26 & $1+$ & 19 & 37 & 109 & 0.68 \\
\hline Spermophilus citellus & $2+$ & $1+$ & 38 & $1+$ & 167 & 81 & 448 & 2.80 \\
\hline Sciurus vulgaris & & $1+$ & 8 & 2 & & $1-$ & 10 & 0.06 \\
\hline Turdus philomelos & 2 & $1+$ & 7 & 4 & 11 & $1-$ & 32 & 0.20 \\
\hline Sturnus vulgaris & 22 & $1+$ & 149 & 114 & 313 & 755 & 1353 & 8.45 \\
\hline Coloelus monedula & & & & $1+$ & & 4 & 9 & 0.06 \\
\hline Phasianus colchicus & $2-$ & $1-$ & 10 & 14 & 177 & 260 & 461 & 2.88 \\
\hline Microtus arvalis & $2-$ & 3- & 6 & 19 & 74 & $1+1080$ & 1185 & 7.40 \\
\hline Nyctalus noctula & & & & & $2-$ & 50 & 50 & 0.31 \\
\hline Talpa europaea & & & & & $1-$ & 28 & 31 & 0.19 \\
\hline Lepus europaeus & $2-$ & $2-$ & 2 & $1-$ & 76 & 175 & 261 & 1.63 \\
\hline Coccothraustes coccothr. & 2 & & 1 & 2 & 8 & $1-$ & 14 & 0.09 \\
\hline Streptopelia decaocto & & & 8 & $1-$ & 14 & 38 & 60 & 0.37 \\
\hline Pica pica & 1 & $1-$ & 0 & 2 & 18 & 51 & 72 & 0.45 \\
\hline Chroicocephalus ridibundus & $1-$ & $2-$ & 0 & $2-$ & 58 & 115 & 176 & 1.10 \\
\hline Cricetus cricetus & 3- & 3- & 5 & 51 & 289 & 483 & 829 & 5.18 \\
\hline Columba livia dom. (n) & 89 & & 577 & 790 & 2908 & 4800 & 9164 & 57.22 \\
\hline$\%$ & 16.76 & & 59.79 & 66.55 & 63.20 & 54.97 & & \\
\hline Coturnix coturnix & 2 & & 1 & 3 & 19 & 46 & 71 & 0.44 \\
\hline Alauda arvensis & 4 & & 2 & 1 & 15 & 26 & 48 & 0.30 \\
\hline Garrulus glandarius & 5 & & 3 & 2 & 6 & 19 & 35 & 0.22 \\
\hline Turdus merula & 4 & & 5 & 3 & 8 & 12 & 32 & 0.20 \\
\hline Passer montanus & & & & & 2 & 15 & 17 & 0.11 \\
\hline Passer domesticus & 2 & & & & 2 & 11 & 15 & 0.09 \\
\hline Corvus frugilegus & 1 & & 1 & 2 & & 6 & 10 & 0.06 \\
\hline Mus cf. musculus & & & & & & 10 & 10 & 0.06 \\
\hline Apodemus flavicollis & 3 & & & & 1 & 6 & 10 & 0.06 \\
\hline Falco tinnunculus & & & & 2 & 1 & 6 & 9 & 0.06 \\
\hline Asio otus & 1 & & 1 & & & 6 & 8 & 0.05 \\
\hline Apodemus sylvaticus & & & & 2 & & 5 & 7 & 0.04 \\
\hline Rattus norvegicus & & & 1 & 1 & 3 & 2 & 7 & 0.04 \\
\hline Corvus cornix & 3 & & 1 & & 2 & 1 & 7 & 0.04 \\
\hline Turdus viscivorus & 2 & & & 1 & 1 & 2 & 6 & 0.04 \\
\hline Mammalia & 97 & $2-$ & 63 & 162 & 619 & $1+1,934$ & 2,875 & 17.95 \\
\hline Aves & 434 & & 902 & 1,024 & 3,982 & 6,792 & 13,134 & 82.01 \\
\hline Amphibia, Reptilia, Pisces & 0 & & 0 & 1 & 0 & 6 & 7 & 0.04 \\
\hline $\bar{\Sigma}$ & 531 & & 965 & 1,187 & 4,601 & 8,732 & 16,016 & 100.00 \\
\hline Diversity Index H' & 2.45 & & 1.60 & 1.45 & 1.61 & 1.80 & 1.84 & \\
\hline
\end{tabular}

pigeons than in eastern Slovakia, where their lower share was compensated with higher representation of the common vole (Tab. 3). This difference was confirmed by the results of our PCA analyses, the ordination diagram from which separated the east Slovakian orographic areas from the western ones (Fig. 9: the first two axes explain $90.3 \%$ of species variability: first axis
$70.3 \%$, second axis $20 \%$ ). The cluster of species in the right-hand part of the graph along the first ordination axis may be characterized generally as the prey of saker falcons which is typical for its higher representation in eastern Slovakia (Košická kotlina Basin, Východoslovenská rovina Plain). This applies mainly to the common vole, whose diet share rises from west to east from 
Fig. 9. Ordination diagram of PCA analyses from monitoring of diet changes relative proportions of species identified in the saker falcon diet and their distribution in the individual nesting periods.

Obr. 9. Ordinačný diagram PCA analýzy sledovania potravných zmien - vzt'ahy medzi druhmi $v$ potrave sokola rároha a ich distribúciou $v$ jednotlivých hniezdnych obdobiach.

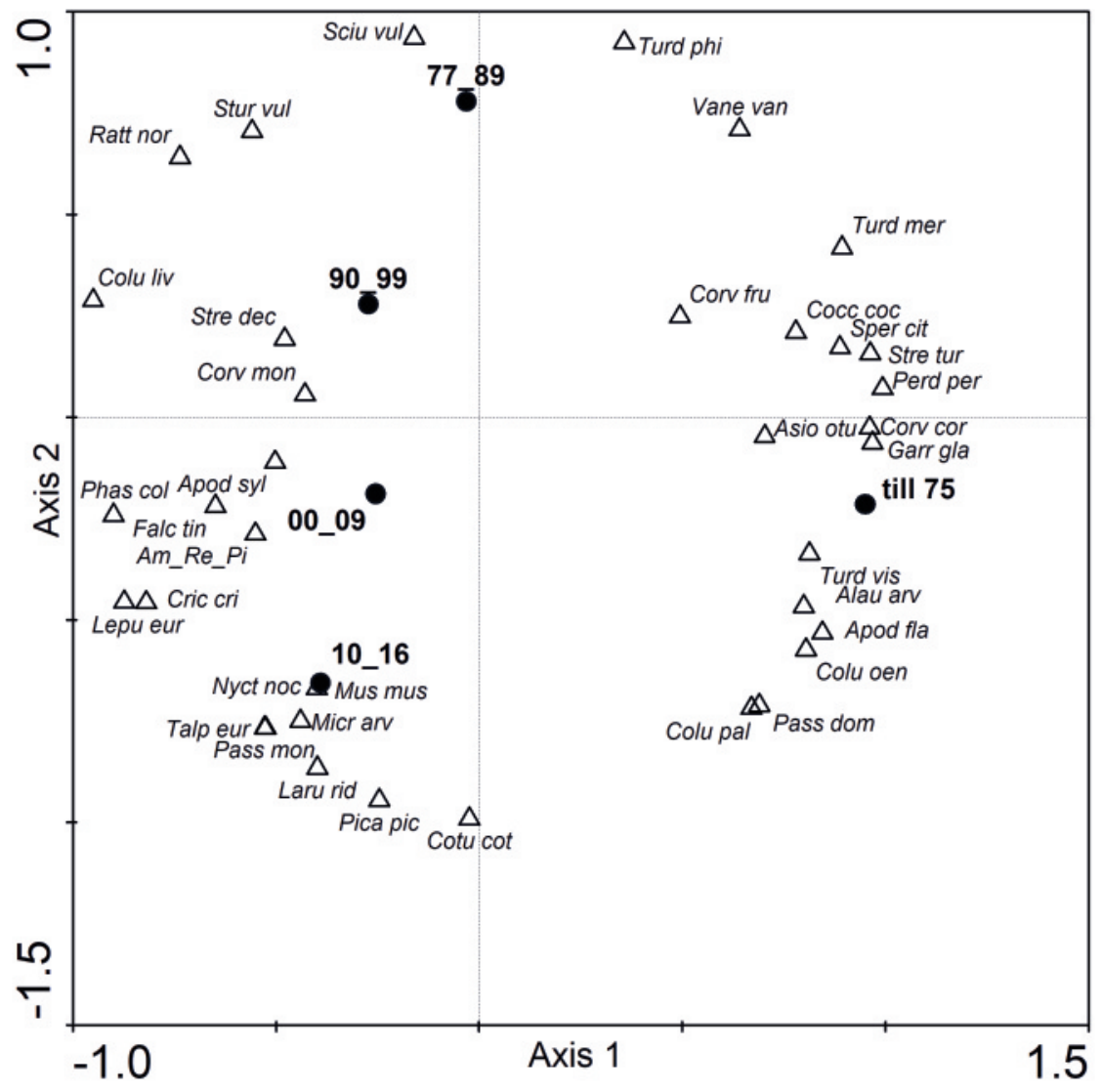

a subdominant share in the Malé Karpaty Mts. and Borská nížina Lowlands to eudominant (Východoslovenská rovina Plain and Košická kotlina Basin). A similar observation applies to the stock dove (Columba oenas), which is found with dominant representation in the diet

Tab. 3. Percentage representation of individual animal prey groups in saker falcon diet in western and eastern Slovakia in 2000-2016.

Tab. 3. Percentuálne zastúpenie jednotlivých skupín živočíchov $\checkmark$ potrave sokola rároha na západnom a východnom Slovensku v $2000-2016$.

\begin{tabular}{ccc}
\hline birds / vtáky & mammals / cicavce & reptiles / plazy \\
\hline \multicolumn{3}{c}{$\begin{array}{c}\text { western Slovakia / Z Slovensko } \\
\text { agro-cenoces / agrocenózy }\end{array}$} \\
81.2 & $\begin{array}{c}18.76 \\
\text { mountains / pohoria }\end{array}$ & 0.04 \\
86.14 & $\begin{array}{c}13.86 \\
\text { floodplains / luhy } \\
10.81\end{array}$ & 0 \\
88.65 & $\begin{array}{c}10.81 \\
\text { eastern Slovakia / V Slovensko } \\
\text { agro-cenoces / agrocenózy } \\
62.32\end{array}$ & 0.54 .46 \\
\hline
\end{tabular}

only in the Košická kotlina Basin. Another numerous prey item in eastern Slovakia is the skylark (Alauda arvensis). In contrast, a species typical for the western part of the country, but almost completely absent from the falcons' diet in eastern Slovakia, is the black-headed gull (Chroicocephalus ridibundus). Relatively large shares in the western diet consist of Phasianus colchicus, Lepus europaeus and (especially historically) Spermophilus citellus. In the area of the Trnavská pahorkatina Uplands the European hamster is so highly represented that it borders on eudominance. Compared with other areas there is also higher incidence here of the common noctule (Nyctalus noctula).

The character of some of the animal remains brought by saker falcons to their nests as food led us to conclude that they could not have been hunted, but found as cadavers (Figs. 10, 11, 12). Body parts from adult hares, hacked off limbs of roe deer (Capreolus capreolus), the head of a fox (Vulpes vulpes) and remains of pheasants could have been picked up after being killed during mowing or harvesting, or by road traffic. Dead animals might also have been taken from other raptor species. 


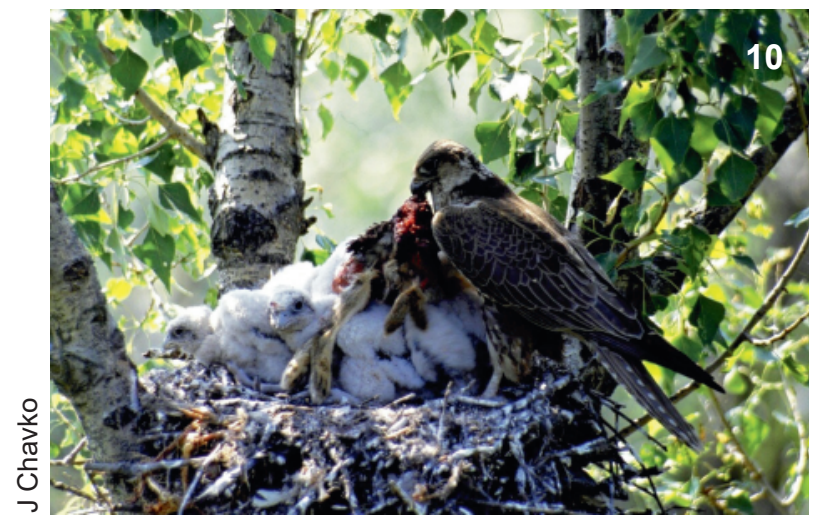

Fig. 10-12. Saker falcon female bringing a hacked-up hare killed during mowing of meadows. This way of acquiring prey was relatively frequent among these falcons (10). Part of a severed limb from a roe deer (Capreolus capreolus) in a box occupied by saker falcons. Deer remains, most frequently young animal limbs, were always found in the form of hacked-up body parts (11). Head of a fox (Vulpes vulpes) found in a box occupied by saker falcons. We may assume that this was another case of brought-in carrion (12).

Obr. 10 - 12. Samica sokola rároha priniesla posekaného zajaca usmrteného pri kosení trávnych porastov. Tento spôsob získavania koristi bol u sokolov rárohov pomerne častý (10). Čast' useknutej končatiny srnca (Capreolus capreolus) v búdke obsadenej sokolom rárohom. Zbytky srnčej zveri, najčastejšie končatiny mlád'at, boli náchádzané vždy v podobe posekaných častí tiel (12). Hlava líšky (Vulpes vulpes), nájdená $v$ búdke obsadenej sokolom rárohom. Možno predpokladat', že aj v tomto prípade bol prinesený nález kadáveru (12).

Differences were also found in the composition of the food spectrum of individual pairs (Appendices 3-6). Some pairs in western Slovakia specialized in hunting black-headed gulls. In this part of the country remains of these gulls were found more frequently in the boxes of pairs nesting close to municipal rubbish dumps, where the gulls were regularly concentrated in large numbers. There was also an interesting find of remains from two yellow-legged gulls (Larus michahellis) in the box of a west Slovakian pair nesting near a rubbish dump visited by flocks of these gulls.

\section{Discussion}

Throughout the period between 1976 and 2016 we monitored the distribution of nesting sites of two saker falcon populations concentrated in upland areas and adjacent lowlands in western and eastern Slovakia. In the former area we recorded nesting by 56 pairs with a total of 516 nestings, and in the latter area we observed nesting by 32 pairs with a total of 246 nestings. The
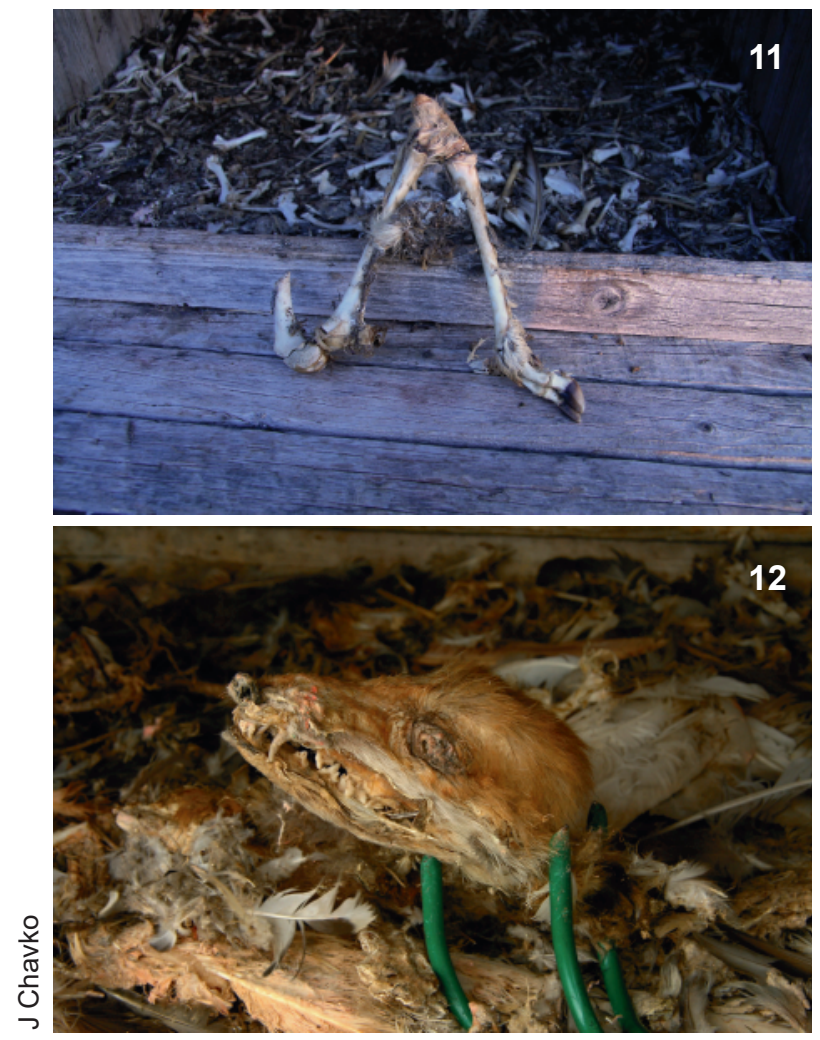

nesting success rates were similar in both regions, the pairs producing an average of 3.2 young in each successful nest. Altogether 1788 young saker falcons were raised in the monitored period as a whole.

We evaluated the results of collections of the falcons' food remains from 49 pairs in the area of western Slovakia in the period 1977 to 2016, and from 12 pairs in eastern Slovakia in the years 2009, 2010, 2015 and 2016. Altogether 17,669 prey items were identified. From 1980 onwards mammals (Mammalia, 19.8\%, 24 species) became gradually less represented as a component in the falcons' diet compared with birds (Aves, 79.9\%, 58 species). In areas of western Slovakia we found stable and predominant proportions of domestic pigeons ranging from $52 \%$ to $62 \%$. The proportion of pigeons was distinctly lower in eastern Slovakia (31.5\%), compensated for by larger shares of common vole, starling (Sturnus vulgaris), Eurasian magpie (Pica pica) and hooded crow (Corvus cornix). The common starling (9.5\%) was a significant prey species in the lowlands of western and eastern Slovakia alike. Mammals were mostly represented by common voles $(9.8 \%)$, European hamsters $(5.3 \%)$, ground squirrels (2.1\%) and hares (1.6\%) (Tab. 1). 
For comparison purposes we also made use of collections from two abandoned nests on rock outcrops in the Malé Karpaty Mts., which were occupied by saker falcons prior to 1975 . Through comparison of prey compositions in individual time periods it is possible to track the changes connected with resettlement of the saker falcon population from the hills down into open countryside (Tab. 3). The indirect ordination diagram produced by PCA distinguished the food spectrum found before 1975 from the prey remains collected in later periods (Fig. 9). The period prior to 1975 was characterized by a relatively small share of the domestic pigeon $(16.8 \%)$ and a higher proportion of wild pigeons Columba oenas and C. palumbus. Before 1975 there was substantially higher diversity of prey species $\left(\mathrm{H}^{`}=2.45\right)$ compared with the last 40 years, during which time the diversity index has ranged between 1.45 and 1.80 , being indirectly dependent on the proportion of $C$. livia f. domestica. Declining from $66.5 \%$ to $55.0 \%$. The share of domestic pigeons peaked in the decade 1990-1999, then gradually declined to a minimum in the period 2010-2016 (Tab. 2).

The change in nesting preferences among saker falcons and their shift from upland nesting sites into open agricultural country, where they make use of boxes and platforms on power line pylons for their nesting, may be explained by their high degree of flexibility and adaptation to new conditions. Their survival in the conditions of this country, however, was dependent on support from human management measures such as the creation of new nesting opportunities (Bagyura et al. 2010, Beran et al. 2012, Rahman et al. 2016). Potential areas were identified in lowland regions all around Slovakia, and altogether 350 nesting boxes were installed on electricity pylons where all pairs in both populations progressively resettled, and a new distribution of nesting sites and feeding territories was established. The upland areas of south-western and south-eastern Slovakia in fact belong among the historically familiar nesting areas of the saker falcon, where the first specific nest finds date from the second half of the 19th century. The core area in western Slovakia was the Malé Karpaty Mts. range, where nesting was first confirmed back in 1931 (Janda 1932) and further information about nest finds or observations of young flying from nests date from 1946, 1949, 1953, 1951 and 1954 (Brtek 1956, Matoušek 1956). Ferianc (1964) estimated the number of saker falcons in the Malé Karpaty Mts. during the $1950 \mathrm{~s}$ and $60 \mathrm{~s}$ at six pairs. The first nest in western
Slovakia though was formally documented in the years 1885 and 1886, on the rock outcrop of Devín Castle near Bratislava. Nests were also found in the Danube wetland forests in 1928, 1933 and 1934 (Kunszt 1929, Matoušek 1933, Csiba 1959), and between 1951-1959 one or two pairs of saker falcons nested in the Šúr nature reserve near Bratislava, where specific nest finds were reported as well (Brtek 1956, Hell 1958a,b, Ferianc 1964). Later nesting was also confirmed in the Považský Inovec range (Hell, 1958a, b, Soviš \& Šindár 1964, Varga 1969), the Strážovské vrchy Hills, the Biele Karpaty Mts. and Pohronský Inovec aMts. gain (Soviš \& Šindár 1964). The first information about saker falcons nesting in eastern Slovakia (Slovenský kras Karst area) was published between the years 1860 and 1870 (Tschusi 1887). Further known data on nesting in that upland area date from 1931 (Lokcsánsky 1931), and then from 1951 and 1958 (Mošanský 1974). Nesting in eastern Slovakia was comprehensively researched by Mošanský (1974). According to his results, these falcons nested in the Slovenský kras Karst area and the Slanské and Volovské vrchy Mts. In the Slovenský kras Karst they occupied nests on rock outcrops, and in the Slanské vrchy Mts. they nested on rocks and in trees as well.

The great increase in numbers of nests on pylons indicates that lowland biotopes are still trophically attractive for saker falcons, despite the worsening state of diversity among food sources (Karp et al 2012). On the other hand we can state that their original nesting conditions have practically disappeared throughout Slovakia as a result of excessively intensive economic exploitation of their previous home habitats (Chavko \& Deutschová 2012). An analogical situation of reduction in trophical and topical conditions, is becoming more and more serious in other European states as well (Donald et al. 2001, Butler et al. 2010, Vermouzek \& Zámečník 2017). The installation of boxes on pylons has led to a clear improvement in nesting conditions for saker falcons across the intensively farmed lowlands (Zink \& Izquierdo 2012, Chavko et al. 2014). As a result, the availability of food may now be considered as the most significant motivating factor for reproduction and successful nesting, which correlates directly with the range of nesting opportunities and the level of incidence of threats (especially human disturbance and bird-related criminality. The main reason for the falcons' resettlement however was the disappearance of most of the colonies of ground squirrel (Ambros 2008) within range of pairs nesting in the hills. Flying to 
and fro deep into the lowlands gathering food became too demanding and inefficient in terms of the birds' energy, which naturally led to resettlement closer to their food sources.

Analogical changes have also taken place in the nesting site distribution of the eastern imperial eagle (Aquila heliaca) in eastern Slovakia. Since 2016 all of the pairs have moved out of the hills and now nest solely in lowland agricultural areas (Danko 2016). In their case too the principal reason was probably the disappearance of the majority of ground squirrel colonies just below the uplands, so the imperial eagles were also forced to resettle deeper in the lowlands in agricultural country where the population of European hamsters was still preserved and poplar stands (mainly poplar windbreaks planted out in the 1960s) provided them with sufficient and suitable nesting places. Influence of the return and spread of peregrine falcons (Falco peregrinus) on the occupancy of original saker falcon nests has not been confirmed, and evidently did not influence the end of their nesting in the uplands either. It has been demonstrated that the first known pair of peregrine falcons took over a nest on a rock outcrop in the Malé Karpaty Mts. (after the last known nesting in 1977) as late as 1994 (Chavko 2008). In that year there were still six saker falcon pairs using tree nests in that range, and no interspecies territorial conflicts were observed. A similar situation also developed in the Slanské vrchy Hills and in the Slovak Karst, where several saker falcon nests on outcrops were occupied by peregrine falcons, but this happened at a time when the saker falcons were already using nesting boxes on pylons in the lowlands.

The success rate levels of 2.4 young per nest on average for all nests and 3.2 young per successful nest recorded in Slovakia are very similar to the levels reported in the surrounding countries (Bagyura et al. 2004, Beran et al. 2012). Differing parameters of the prey spectrum apparently do not significantly influence the nesting success rates, and it has been shown that nesting pair numbers and size of area of nesting distribution are influenced to a decisive degree by the sufficiency and range of prey during the reproduction season (Dixon 2009).

One of the significant negative factors which reduced saker falcons' nesting success rates in the past was nest robbery. The first information about nest robberies in the Malé Karpaty Mts. was published by Ferianc back in 1977, who stated that the impact of falconry and commercial interests had already led to stagnation in progress of the species, and that saker falcons had stopped nesting in the Male Karpaty Mts. in 1973. During monitoring of the population studied in western Slovakia between the years 1976 and 2006 there were 28 recorded instances of suspected nest robbery (Appendix 7). The number of cases included only those involving pairs which had evidently nested, but the nests were later found empty with marks of climbing on the tree trunks. The real number of robberies was probably higher, because some nests may have been robbed early, just at the time of egg-laying, and we would not necessarily have discovered such cases. Our estimate is that between 1965 and 1999 as many as 175 nests were robbed (Chavko 2002a). The greatest threat due to nest robbery appeared after 1988, putting the survival of the saker falcon population itself at risk, as at that time it consisted of just 7-11 pairs. For this reason from 1991 till 1994 all occupied nests in the Malé Karpaty Mts. were physically guarded round the clock. This guarding was performed on shifts by hundreds of trained volunteers, mostly Czech and Slovak students. We recorded several attempts at robbery even of the guarded nests, but thanks to the well-organized nest protection the robbers did not succeed in taking anything at all. In the years immediately following the attempts stopped completely, and later there were only occasional cases. The last suspected robbery was recorded in 2006. We assume that this robbery ceased here mainly because after the dissolution of the Soviet Union, falconers' interest in young taken from the wild became focused on countries with populations of falcon species with greater body weight, for example Kazachstan (for more see Kovács et al., 2014), and moreover saker falcons were superseded in falconers' collections above all by peregrine falcons and gyrfalcons (Falco rusticolus) and cross-breeds of these. Large falcons (Falco rusticolus, Falco peregrinus, Falco cherrug) living in the wild are threatened mainly due to megalomaniac breeding by Arab falconers and the resulting commerce with birds, and by the involvement of raptor collectors from other countries (Levin 2000, 2008).

The most significant current threats to the maintenance of stability and nesting success rates within the saker falcon population in Slovakia may be considered as the environmentally inappropriate manner of intensive agricultural and forestry exploitation of the countryside, and then certain other kinds of bird-focused criminality, primarily illegal culling by shooting and poisoning. The problem is considerably exacerbated by the insufficient level of law enforcement and by the ignoring or lack of application of 
international conventions dealing with the protection of biotopes and endangered species.

The original biotopes of the saker falcon were grassland steppes, which have progressively given way to agricultural land-use, and practically disappeared in Slovakia after the 1950s and 60s with the exception of small areas of meadows and pasture land (Chavko 2002a). One of the consequences of the post-war changes in political orientation was a significant reform of the strategy of agricultural land-use. Political decisions on consolidation and collectivization produced large blocks of land adapted for mechanized farming, but resulting in unsuitable changes to biotopes, the effects of which persist to the present-day. We can state, therefore, that the saker falcon now nests and acquires its food in secondary, non-original and altered biotopes. These factors have also had significant impact on the diversity and numbers of the dominant prey species, causing a drop in both. The first species to disappear from the countryside was the ground squirrel, and recent years have also seen a decline in the common hamster. There has been considerable reduction in the small animal count as well, especially partridges, pheasants and hares (Bro et al. 2000, Newton 2004). The influence of chemical elimination of small, ground-based mammals has been particularly negative, above all of the common vole. It was not possible to precisely quantify the impact of poisoning in our research framework, but we definitely recorded the end of nesting by a specific pair of falcons in the Trnavská pahorkatina Uplands (western Slovakia) which had been nesting in the vicinity of around 200 hectares of lucerne fields with large numbers of common voles. We observed them hunting here, the male primarily hunting voles and taking them back to the young. In the very course of their nesting pesticide was applied against the voles, and nesting by this pair of falcons ceased in 2016. There has been particular impact on biodiversity and consequently also on quantity and range of prey due to extensive agriculture (Vermouzek 2017).

There is a persistent threat to the falcons from the dogma of the harmful influence or raptors on small animal species. There is a rising trend in finds of illegally killed raptors, which only intensifies the problem of growing vulnerability in the population of these birds. In all parts of Slovakia, with the exception of the built-up areas of towns and villages, people are intensively pursuing their hunting rights. In our monitored period between 1976 and 2016, above all in the lowlands, every year there were numerous instances of birds of prey being killed predominantly by illegal means, whether shooting, poisoning or trapping. Apart from serious injury, the use of lead shot also causes secondary poisoning, but illegal prey poisoning represents a more serious threat to the saker falcon (Kovács et al. 2014). All of the falcons' nesting areas in the lowlands are intensively used by hunters, and in most cases we encountered their incomprehension with regard to the importance and irreplaceability of raptors in our ecosystems (Deutschová et al. 2018). One case of poisoning, serious but by no means unique, was recorded in the Trnavská pahorkatina Uplands (south-western Slovakia) in March 2009, when in just one hunting ground 22 common buzzards (Buteo buteo), 4 saker falcons and 5 magpies were found poisoned. Domestic pigeons and hares were used as bait (Figs. 13, 14) contaminated with carbofuran. Additionally, several instances of harmed saker falcon individuals were recorded in western Slov-
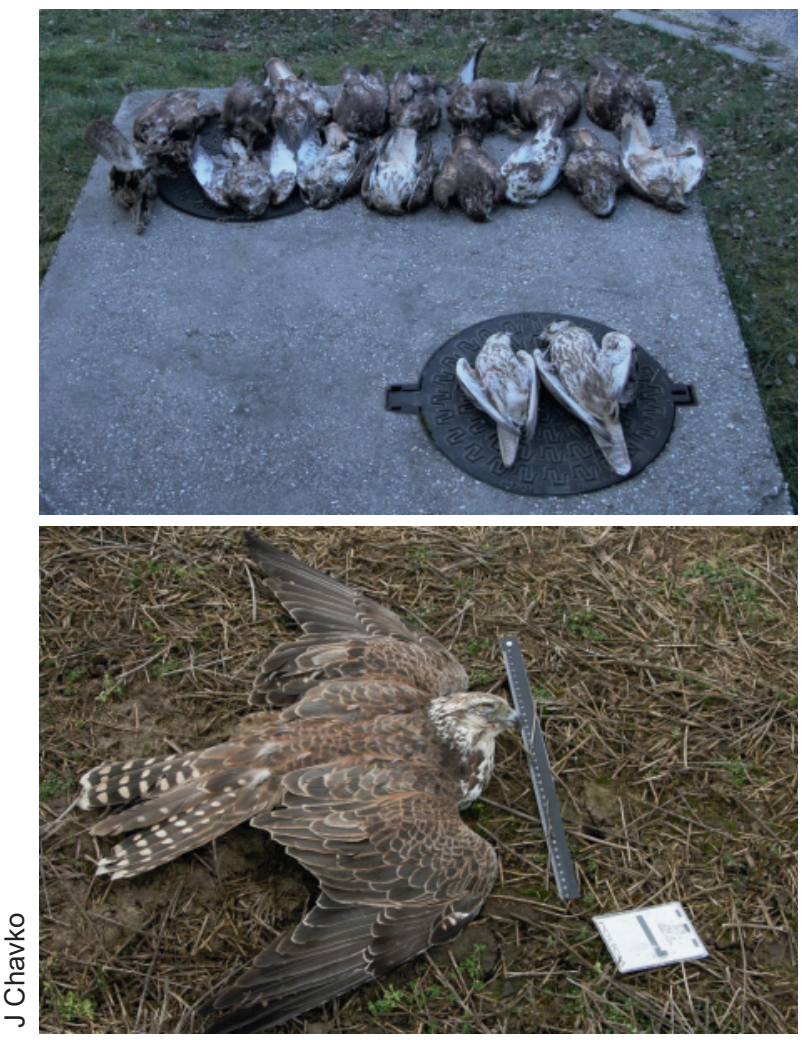

Figs. 13, 14. Finds of killed saker falcons and common buzzards (Buteo buteo). Veterinary examination confirmed the cause of death as carbofuran pesticide poisoning.

Obr. 13, 14. Nálezy usmrtených sokolov rárohov a myšiakov hôrnych (Buteo buteo). Veterinárnym vyšetrením bola potvrdená príčina úmrtia - otrávenie carbofuranom. 
akia in which the use of poison was suspected, but it was not possible to specify the source or the cause of the poisoning. Our assumption is that poisoning and illegal shooting represent an essential threat to the stability of the west Slovakian saker falcon population and other mainly carrion-eating species of raptor. Furthermore, the large proportion of domestic pigeons in the saker falcon diet is establishing in them an increasingly dangerous dependence on this kind of prey, evoking unfriendly reactions among pigeon fanciers which may in future become a definite threat to sakers, similarly as for peregrine falcons already (Chavko 2002b).

During the course of the monitored period we recorded three deaths resulting from collisions with electric power lines. Lightning strikes on pylons caused the deaths of four young in one nesting box in western Slovakia, and a total of nine young in three boxes in the eastern part of the country. The greatest threat in this context however may be seen in short-circuits on the cross-bars of poles on $22 \mathrm{kV}$ overground power lines, on which we recorded the deaths of 14 individuals altogether. These medium-voltage lines threaten the falcon population throughout Europe, with thousands of kilometres of power lines crossing all of their nesting and migrating territories (Chavko 2002a, Beran et al. 2012, Kovács et al. 2014). It may be assumed namely that the said finds are only an indication of the extent of bird injuries on power lines, and that the real mortality rate will be substantially higher. A considerable majority of killed individuals fails to be recorded, mainly because a large proportion of them tends to be removed by predators (Vulpes vulpes, Meles meles), so only a fraction of the true number of bird deaths is registered. Increased attention is being paid to this problem in Slovakia at the present time, as a result of which 62,000 power line pylons have been ecologized, around one third of which $(18,000)$ stand in the home territories of the saker falcon (Gális et al. 2018, 2019).

Initial growth in the number of saker falcon nesting sites in Slovakia in the late 1980s later gave way to stagnation in the numbers of nesting pairs, which was probably linked with changes in the range and availability of prey. The greatest share of prey now consists of domestic pigeons, while species such as ground squirrel, hamster, vole, partridge and lapwing, which might compensate for seasonal or local lack of pigeons, are reduced to minimum availability as a result of environmentally inappropriate agricultural practices. The distinct drop in numbers of these species most likely underlies their reduced share in the falcons' diet during the first monitored nesting periods $1977-1989$ and 19901999. This is probably a manifestation of the effect of the ongoing decline in biodiversity, and thus also of the decline in density of other species which are potential prey for the saker falcon. In eastern Slovakia the low number of nesting sites persists, which for a long time has not exceeded the annual frequency of 12 nesting pairs. Domestic pigeons are represented with a share of just $31.5 \%$ in the saker falcon diet in eastern Slovakia, i.e. one half of their share in the western part of the country. The availability of dominant prey species has also dropped considerably in eastern Slovakia, and the lack of small mammals is now equally serious, particularly the growing lack of ground squirrels as well as of common hamsters. Currectly prospering saker falcon pairs probably occupy only those biotopes which are viable from the points of view of prey availability and relative safety from predator threats, in this case mainly kleptoparasitism by the numerous population of imperial eagles in eastern Slovakia. The lack of suitable food meant that in nests of the east Slovakian population we found remains of small prey species apart from voles, for example also lizards (Lacerta agilis) and beetles (Coleoptera). The numbers of finds of small, land-based mammals, songbirds and other small creatures must be considered as clearly underestimated, however. After feeding there were only very small amounts of their remains left in the nests, and this also influenced the counts recorded. Very small prey was often totally consumed, and was then digested without remains in the birds' guts.

Similarly as in our study, higher incidence of birds in the falcons' diet is also found in certain other areas around Europe, for example in France, Croatia, the Czech Republic and Hungary (Kovács et al. 2014), but also in the Middle East (Izrael), or in China (Wu 2011), where the proportion of birds was found to be $52 \%$ (44\% when recalculated as biomass). On the other hand, mammals are still a dominant diet component in Romania and Bulgaria (Baumgart 1971), and mainly in Asia. In central Kazachstan the red-cheeked ground squirrel (Spermophilus erythrogenys) and great gerbil (Rhombomys opimus) form the dominant component (together almost 50\%) in the saker falcons' diet (Nedyalkov et al. 2014) These are medium-sized mammals like those which used to form the dominant diet component in Slovakia in the past (Chavko et al. 2014). Similar incidence of mammals (together up to $70 \%$ ) is reported in Mongolia (Gombobaatar et al. 2006), of which the dominant prey is Brandt's vole (Lasi- 
opodomys brandtii; equivalent to common vole in the conditions of central Europe). These data suggest that the saker falcon is a species which focuses primarily on hunting mammals, and it is a form of secondary feeding opportunism which has made it adapt to the local availability of prey, which in central European conditions means mainly pigeons (Balázs 2008, Papp \& Balázs, 2010, Chavko \& Deutschová 2012). Pigeons are otherwise known as the preferred prey during the winter months, when in the case of insufficient food in their nesting areas the falcons move to their wintering grounds where there are higher concentrations of prey (Baumgart 1991, Snow and Perrins 1998, FergusonLees \& Christie 2001), especially pigeons in the vicinity of larger towns and farms.

In western Slovakia we recorded specialization in hunting seagulls among some saker pairs, especially the black-headed gull (Chavko et al. 2014). Similar specialization was found by Horák (1998) in southern Moravia. The latter observed that the saker falcon hunted gulls in the fields, not in their nesting colonies. Moreover, food analysis results clearly indicated that some pairs acquired their food by picking up dead animals they had found, or by stealing them from other raptor species. These were above all animals which had been killed as a result of human activity, during mowing or harvesting, or by road traffic, but also by illegal poisoning, for example by deliberate poisoning of small, ground-based mammals as bait (Figs. 13, 14). It may be stated, therefore, that the saker falcon is to some extent a cadaverivorous species.

Kleptoparasitism was commonly observed in the monitored population as a way for the falcons to acquire food, similarly as is known in other areas where they occur (Braun \& Lederer 1996, Kovács et al. 2014). In the course of nesting we saw individual parents take prey from common kestrels (Falco tinnunculus), western marsh harriers (Circus aeruginosus), common buzzards and other raptors. Young saker falcons having flown their nests also commonly attacked other raptor species, trying to take the prey they had hunted. On the other hand, we also recorded numerous instances of eastern imperial eagles, common buzzards, roughlegged buzzards (Buteo lagopus), northern goshawks (Accipiter gentilis) and white-tailed sea-eagles (Haliaeetus albicilla) snatching prey from saker falcons.

Moreover, we recorded one case of a common kestrel itself being hunted down, but without being consumed as food. In early May 2016 a male saker falcon was sitting by his nesting box with one of his young and noticed a kestrel fly up to its own box two pylons away. The falcon immediately took off and flew in attacking mode towards the rear of the kestrel's box, so as not to be observed. Then he made a sudden turn and managed to force the kestrel into the box (Fig. 15). After a moment he flew out of the box again carrying the lifeless kestrel in his claws, but after about 30 metres he dropped the corpse on the ground and paid no more attention to it. It is interesting that the falcon did not take his catch back to his young. This was most likely a case of territorial behaviour, as kestrels often nastily harass saker falcons during the course of their nesting, and this may have given rise to the falcon's interest in ridding his brood of the kestrel's presence.

During the period 1976-2016 in western Slovakia and the period 1979-2016 in the eastern part of the country, we recorded nesting by a great majority of all the monitored pairs of saker falcons (we estimate that we checked practically all the pairs, in any case roughly 95-97\% of nestings in the whole population). In western Slovakia we monitored nesting by 56 pairs, and between the years 1976 and 2016 we recorded a total of 514 nestings. In eastern Slovakia between the years 1979 and 2016 we recorded nesting by 32 pairs, and in the monitored period we recorded altogether 245 nestings there.

In conclusion we can briefly state the following: we have described the process and course of changes in the saker falcons' preferred nesting habitats in two geographical areas within Slovakia, and the move of the

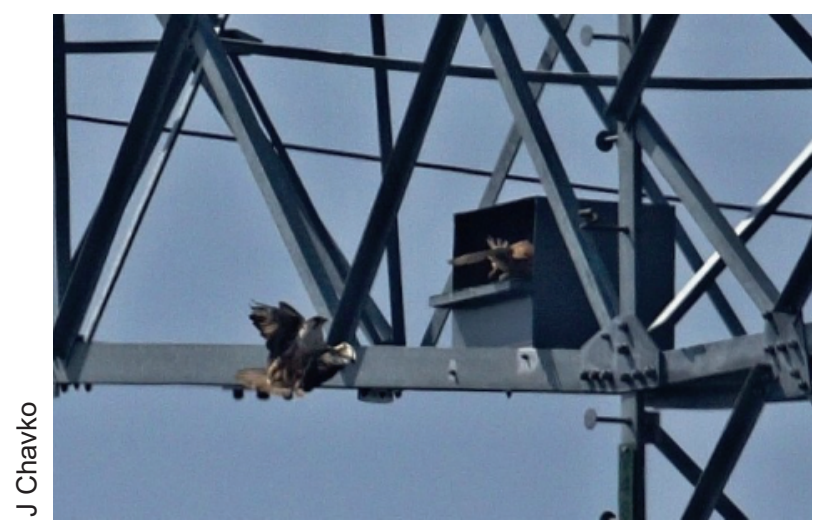

Fig. 15. Attack by a male saker falcon on a common kestrel in which the death of the kestrel was recorded, although the attack was not associated with prey-hunting behaviour.

Obr. 15. Útok samca sokola rároha na sokola myšiara. Zdokumentované bolo usmrtenie sokola myšiara, pričom lov nesúvisel s potravovým správaním. 
nesting population from the hills and wetlands into agricultural countryside. We have compared the reproductive success rate among pairs nesting in trees and on rock outcrops with that achieved by pairs nesting in boxes and on platforms on power line pylons amidst farmland. We found significantly higher success rates among saker falcons nesting in agricultural country compared to those nesting in the uplands, with similar results in both monitored geographical areas (western and eastern Slovakia). In agricultural country an average of $81.1 \%$ of all nests were successful, producing on average 2.7 young per nest overall, or 3.3 young per successful nest. In the uplands on average 1.7 young flew from each nest overall, or 2.9 young per successful nest, with an overall success rate of just $57.1 \%$ nests.

We have compared the spectrum of prey hunted by saker falcons going back over the past 40 years and more within the monitored nesting areas of the Slovakian saker population, and also compared the range of prey with regard to the different orographic areas within Slovakia. We found that from 1980 onwards mammals (Mammalia) as a component of the falcons' diet became progressively less important than birds. The most frequently hunted prey species was the domestic pigeon, the incidence of which in the food spectrum amounted to $57 \%$ on average during the monitored period as a whole. There were also relatively frequent catches of starlings, common voles and hamsters. Together with the move of nesting pairs into the agricultural lowlands there occurred a change in the falcons' preference for certain species of mammal, with others assuming higher proportions in the falcons' diet. We also found differences in the diet composition of nesting falcons between the eight orographic areas studied in western and eastern Slovakia, as well as between the five subdivided time spans making up the whole monitored period when comparing the individual orographic areas. Whereas the common pigeon was clearly the highest represented prey species in the falcons' diet in all types of nesting biotope, in western Slovakia they hunted approximately double the number of pigeons compared with eastern Slovakia, where their lower share was compensated for with a higher incidence of the common vole. From all the pairs of saker falcon in the monitored period as a whole we gathered 17,669 samples of prey from 56 pairs (40 nesting in lowland agricultural country, and 16 in upland and wetland forest areas).

The results of our identification of the range of threats faced by saker falcons demonstrate that in the interests of sustainability of the population it is neces- sary to accept that they are dependent on human management measures, especially the creation, restitution and maintenance of sufficient numbers of nesting boxes, as well as restoration of the former diversity among the falcons' original sources of prey, and diminution of the impact of human criminality.

\section{References}

Ambros M 2008: Stav poznania rozšírenia sysl'a pasienkového (Spermophilus citellus) na Slovensku v rokoch 1996 až 2008 [Current knowledge on the distribution of the European ground squirrel (Spermophilus citellus) in Slovakia in 1996-2008]. Lynx (Praha) 39(2): 219-233. [In Slovak with English abstract]

Bagyura J, Haraszthy L \& Szitta T 1994: Feeding biology of the saker falcon Falco cherrug in Hungary, 397-401. In: Meyburg B-U \& Chancellor R (eds), Raptor Conservation Today. WWGBP \& Pica Press. Berlin \& Mountfield.

Bagyura J, Szitta T, Haraszthy L, Demeter I, Sándor I, Dudás M, Kállay Gy \& Viszló L 2004: Population trend of the saker falcon Falco cherrug in Hungary between 1980 and 2002, 663-672. In: Chancelor RD \& Meyburg B-U (eds), Raptors Worldwide. Proceedings of the World Conference on Birds of Prey and Owls. Budapest Working Group on Birds of Prey and Owls, MME/ Birdlife Hungary, Berlin \& Budapest.

Bagyura J, Fidlóczky J, Szitta T, Prommer M, Tihanyi G, Zalai T, Balázs I, Váczi M, Viszló L, Klébert A, Haraszthy L, Tóth I, Török HA, Demeter I, Serfőző J, Pigniczki C \& Kazi R 2009: Annual report of the saker falcon working group - 2009. MME/BirdLife Hungary.

Bagyura J, Fidlóczky J \& Prommer M 2010: Conservation of Falco cherrug in the Carpathian Basin (LIFE06 NAT/H/000096). MME/BirdLife Hungary, Budapest.

Balázs I 2008: Recent occurrence of saker falcons in an urban environment in Hungary. Falco 31: 4-5.

Baumgart W 1971: Beitrag zur Kenntnis der Greifvögel Bulgariens. Beitr. Vögelkd.: 17.

Baumgart W 1980: Der Sakerfalke Falco cherrug. Neue Brehm-Bücherei 514: 1-160.

Baumgart W 1994: Saker falcon Falco cherrug, 198199. In: Tucker GM \& Heath MF (eds), Birds in Europe: their conservation status. BirdLife International (Conservation Series 3), Cambridge.

Beran V, Hlaváč V \& Bělka T 2009: Development of the 
peregrine and saker falcon populations in the Czech Republic in the last 30 years, 757-764. In: Sielicky J \& Mizera T (eds), Peregrine falcon populations status and perspectives in the $21^{\text {st }}$ century. Turul Poznań University of Life Sciences Press, WarsawPoznań.

Beran V, Horák P, Škorpíková V \& Horal D 2010: Vývoj hnízdní populace raroha velkého (Falco cherrug) V České republice v letech 1999-2010 [Development of the saker falcon (Falco cherrug) breeding population in the Czech Republic between 1999-2010]. Crex 30: 76-94. [In Czech with English summary]

Beran V, Škorpíková V, Valášek M, Horal D \& Horák P 2012: The breeding population of saker falcon (Falco cherrug) in the Czech Republic between 1999-2010. Aquila 112: 21-30.

BirdLife International 2010: Saker falcon (Falco cherrug): how to interpret new population estimates? Saker populations and trade (2).xls Retrieved October 29, 2010 from http://www.birdlifeforums.org/ WebX/.2cba6d3d.

Braun B \& Lederer E 1996: Kleptoparasitism by a saker falcon (Falco cherrug), robbing food from marsh harriers (Circus aeruginosus). Egretta 39: 116.

Bro E, Sarrazin F, Clobert J \& Reitz F 2000: Demography and the decline of the grey partridge Perdix perdix in France. Jorunal of Applied Ecology 37: 432-448.

Brtek V 1956: Zpráva o hniezdení rároha vel'kého (Falco cherrug) v Bratislavskom kraji [Nachrichten über das Nisten des Falco cherrug-Würgfalken im Kreis Bratislava]. Sborník Krajského múzea V Trnave 2: 77-80. [In Slovak with German summary]

Brtek V 1974: Die Verbreitung des Ziesels (Citellus citellus L.) im slowakischen Gebiet des Karpatenbogens und einige ökologische Bemerkungen dazu. Biológia 29: 393-399.

Butler SJ, Boccaccio J, Gregory RD, Voříšek P \& Norris K 2010: Quantifying the impact of land-use change on European farmland bird populations. Agriculture, Ecosystems and Environment 137: 348-357. DOI: 10.1016/j.agee.2010.03.005.

Chavko J 2010: Trend and conservation of the saker falcon (Falco cherrug) population in western Slovakia between 1976 and 2010. Slovak Raptor Journal 4: 1-22. DOI: DOI: 10.2478/v10262-0120040-4.

Chavko J \& Deutschová L 2012: Population of the saker falcon (Falco cherrug) in western Slovakia between 1976 and 2010. Aquila 119: 57-64.

Chavko J, Slobodník R, Deutschová L, Lipták J, Mihók J, Obuch J \& Nemček V 2014: The saker falcon (Falco cherrug) population, diet and nest boxes in Slovakia: LIFE-project report 2011-2014. Slovak Raptor Journal 8 (2): 73-86. DOI: 10.2478/srj-20140009.

Chavko J 2002a: Sokol rároh (Falco cherrug) [The saker falcon (Falco cherrug)], 214-216. In: Danko Š, Darolová A \& Krištín A (eds): Rozšírenie vtákov na Slovensku. Birds Distribution in Slovakia. Veda, Bratislava. [In Slovak with English summary]

Chavko J 2002b: Sokol st'ahovavý (Falco peregrinus) [The peregrine falcon (Falco peregrinus)], 216-217. In: Danko Š, Darolová A \& Krištín A (eds): Rozšírenie vtákov na Slovensku. Birds Distribution in Slovakia. Veda, Bratislava. [In Slovak with English summary]

Chavko J \& Deutschová L 2012: Population of the saker falcon (Falco cherrug) in western Slovakia between 1976 and 2010. Aquila 119: 57-64.

Chernel I 1899: Magyarország madarai különös tekintettel gazdasági jelentőségökre. Második könyv [Birds of Hungary with special emphasis on their economic importance, second volume]. Magyar Ornithologiai Központ, Budapest. [In Hungarian]

Chavko J, Siryová S \& Maderič B 2008: The population of peregrine falcon in Slovakia 1994-2007, 65-76. In: Sielicki J \& Mizera T (eds): Peregrine falcon populations - status and perspectives in the $21^{\text {st }}$ Century. Turul \& Poznań University of Life Sciences Press, Warsaw \& Poznań.

Csiba L 1959: Kiegészítő adatok Dr. Keve András „Adatok a Közep-Duna madárvilágához“ c. munkájához. Supplementary data to Dr. A. Keve's Paper: "Data to the Ornis of the Middle-Danube". Aquila 65: 302304, 357-358.

Danko Š, Diviš T, Dvorská J, Dvorský M, Chavko J, Karaska D, Kloubec B, Kurka P, Matušík H, Peške L, Schröpfer L \& Vacík R 1994: Stav poznatkov o početnosti hniezdnych populácií dravcov (Falconiformes) a sov (Strigiformes) v Českej a Slovenskej republike k roku 1990 a ich populačný trend $\mathrm{v}$ rokoch 1970-1990 [The state of knowledge of breeding numbers of birds of prey (Falconiformes) and owls (Strigiformes) in the Czech and Slovak Republics as of 1990 and their population trends in 1970-1990]. Buteo 6: 1-89.

Danko Š, Lešo $P$, Pjenčák $P$, Lipták J, Fulín $M$, 
Pačenovský S, Mošanský A, Mošanský L, Olejár R, Potočný R, Krištín A, Šimák L, Buday M, Fecko M, Urban P, Imrich P, Balla M \& Žigraj J 2010: Vtáctvo Slanských vrchov a ich predhorí [Birds of the Slanské vrchy Mountains and their foothills]. Slovenská ornitologická spoločnost'/BirdLife Slovensko, Bratislava. [In Slovak with English summary]

Danko Š 2016: Monitoring, management and protection of eastern imperial eagle nesting sites in eastern Slovakia in 2016. Report by Raptor Protection of Slovakia. Ochrana dravcov na SLovensku, Bratislava.

Deutschová L, Chavko J \& Doktorová S 2018: Z lásky ku krivým zobákom - Všetci za dravce [For the love of crooked beaks - All for raptors], 30. In Kubovčík V \& Stašiov S (eds): Zborník abstraktovz vedeckého kongresu „Zoológia 2018“. Technická univerzita vo Zvolene, Zvolen. [In Slovak]

Dixon A 2009: Saker falcon breeding population estimates. Part 2: Asia. Falco 29: 4-12.

Donald PF, Green RE \& Heath MF 2001: Agricultural intensification and the collapse of Europe's farmland bird populations. Proc. R. Soc. Lond. B 268: 25-29.

Ferguson-Lees J \& Christie D A 2001: Raptors of the World. Christopher Helm, London.

Ferianc O 1964: Stavovce Slovenska II. Vtáky I. [Vertebrates of Slovakia II. Birds I.] Vydavatel'stvo SAV, Bratislava. [In Slovak]

Ferianc O 1977: Vtáky Slovenska 1 [Birds of Slovakia, vol. 1] Veda, Bratislava. [In Slovak]

Frey H \& Senn H 1980: Zur Ernährung des Würgfalken (Falco cherrug) und Wanderfalken (Falco peregrinus) in den niederösterreichischen Voralpen. Egretta 23: 31-38.

Gális M, Deutschová L, Šmídt J, Hapl E \& Chavko J 2016: Vysoká cena za pohodlie alebo rizikovost' elektrických vedení pre vol’ne žijúce druhy vtákov [High price for comfort, or the degree of risk on power lines for bird species living in the wild], 7779. In: Krumpalová Z, Zigová M, Tulis F (eds), Zborník príspevkov $\mathrm{Z}$ vedeckého kongresu "Zoológia 2016 " [Pro eeding from the science congress "Zoology 2016"]. Constantine the Philosopher University in Nitra, Nitra. [In Slovak with English Summary].

Gális M, Deutschová L, Šmídt J, Hapl E \& Chavko J 2017: Vplyv konštrukčného prevedenia konzoly stĺpu $22 \mathrm{kV}$ a jej ošetrenia na úmrtnost' vtákov. [Influence of $22 \mathrm{kV}$ pylon cross-bar construction type and protection devices on bird mortality], 5960. In: Bryja J, Horsák M, Horsáková V, Řehák Z \& Zukal J (eds), Zoologické dny Brno 2017. Sborník abstraktů z konference 9.-10. února 2017 [Zoology Days, Brno. Collection of abstracts from the conference]. Institute of Vertebrate Biology Czech Academy of Sciences. Brno. [In Slovak]

Gális M, Deutschová L, Šmídt J, Hapl E \& Chavko J 2018: Bezpečne a plynulo vd'aka projektu LIFE Energia [Safe flights - thanks to LIFE Energy project], 39. In: Kubovčík V \& Stašiov $S$ (eds), Zborník abstraktov z vedeckého kongresu „Zoológia 2018“ [Proceeding from the science congress "Zoology 2018"]. TU, Zvolen. [In Slovak]

Gális M, Slobodník R, Chavko J, Deutschová L, Hapl E, Šmídt J 2019: Energia v krajine - elektrické vedenia a ochrana prioritných druhov vtákov $\mathrm{v}$ územiach Natura 2000 [Energy in the land - power lines and protection of priority bird species in the Nature 2000 areas], 62. In: Bryja J, Horsák M, Horsáková V \& Zukal J (eds), Zoologické dny Brno 2019. Sborník abstraktů z konference 7.-8. února 2019 [Zoology Days, Brno 2019. Abstracts from the conference 7-8 February 2019]. Ústav biologie obratlovců AV ČR, Brno.

Galushin V, Moseikin V \& Sanin N 2001: Saker falcon breeding range and populations in European Russia, 34-43. In: Galushin V et al. (eds), Proceedings of the II. International conference on the saker falcon and houbara bustard. Mongolia, 1-4 july 2000. Ulaanbaatar, Mongolia.

Gamauf A 2012: A preliminary overview of raptor monitoring in Austria. Acrocephalus 33: 159-166.

Gamauf A \& Dosedel R 2012: Satellite telemetry of saker falcons (Falco cherrug) in Austria: juvenile dispersal at the westernmost distribution limit of the species. Aquila 119: 65-78.

Gombobaatar S, Uuganbayar C, Sumiya E, Potapov \& Fox N 2006: Diet studies of breeding and wintering saker falcons Falco cherrug in central Mongolia. Populationsökologie Greifvogelund Eulenarten 5: 203-214.

Grulich I 1960: Sysel obecný Citellus citellus L. V ČSSR [The European ground squirrel Citellus citellus L. in Czechoslovakia]. Práce Brněnské základny Československé akademie věd 32(2): 437-561. [In Czech with English summary]

Hell P 1958a: K rozšíreniu rároha na Slovensku [On the distribution of saker falcon in Slovakia]. Živa 6: 32. [In Slovak] 
Hell P 1958b: Néhány ragadozó-madártaniy jegyzet Nyugat-Szlovákiából [A few ornithological notes about raptorial birds in western Slovakia]. Aquila 65: 279-342. [In Hungarian]

Horák P: Výrazná potravní specializace páru raroha velkého (Falco cherrug) na jižní Moravě [Distinct specialization in the diet of a pair of saker falcons in southern Moravia]. Buteo 10: 85-88. [In Czech with English summary]

Horák P 2000: Vývoj populace raroha velkého (Falco cherrug) na Moravě v letech 1976-1998 [Development of saker falcon (Falco cherrug) population between 1976-1998 in Moravia (Czech Republic)]. Buteo 11: 57-66. [In Czech with English summary]

Hrabar A 1932: Ptactvo na Podkarpatské Rusi. (Preklad prof. A. Malicha) [Birdlife in Subcarpathian Ruthenia (translated by Prof. A. Malich)] Sborník zemské muzejní společnosti v Užhorodě: 59-86.

IUCN 2010. IUCN Red List of Threatened Species. Version 2010.4. Retrieved October 29, 2010 from http://www.iucnredlist.org.

Janda J 1932: Raroh velký evropský (Falco cherrug cherrug Gray) na Slovensku [Saker falcon (Falco cherrug cherrug Gray) in Slovakia]. Věda prrírodní 13: 107-109. [In Czech]

Karp DS, Rominger AJ, Zook J, Ranganathan J, Ehrlich PR \& Daily GC 2012: Intensive agriculture erodes biodiversity at large scales. Ecology Letters, 15: 963970. DOI: 10.1111/j.1461-0248.2012.01815.x.

Karyakin IV 2001: The saker falcon in Tuva. Falco 15: 8-10.

Karyakin IV 2005: Saker falcon in eastern Europe stay is one step to tragedy. Raptors Conservation 2: $12-16$.

Karyakin IV 2008: Saker falcon in Russia. Raptors Conservation 12: 28-47.

Kashkarov RD \& Lanovenko EN 2011: Action plans on conservation of the world's endangered bird species in Uzbekistan: Saker falcon and Egyptian vulture. Society for Protection of Birds, Tashkent. [in Russian].

Kovalík P, Topercer J, Karaska D, Danko Š \& Šrank V 2010: Zoznam vtákov Slovenska k 7. 4. 2010 [A checklist of birds of Slovakia to April 7, 2010.]. Tichodroma 22: 97-108. [In Slovak with English summary]

Kovács A, Williams NP \& Galbraith C 2013: SakerGAP Stakeholder Analysis. Saker Falcon Task Force Objective 5 Report, 47-53. In: Williams, NP, Galbraith C \& Kovács A (eds), Compilation Report on WorkPlan Objectives $4-8$, including a modelling framework for sustainable use of the saker falcon Falco cherrug. CMS Raptors MOU Coordinating Unit, Saker Falcon Task Force, Abu Dhabi.

Kovács A, Williams NP \& Galbraith CA 2014: Saker falcon Falco cherrug global action plan (SakerGAP), including a management and monitoring system to conserve the species. Raptors MOU Technical Publication No. 2. CMS Technical Series No. 31. Coordinating Unit - CMS Raptors MOU, Abu Dhabi, United Arab Emirates.

Kunszt K 1929: A kerecsen sólyom, vagy ráró (Falco lanarius), mint fészkelő madár a Csallóközben [Saker falcon (Falco lanarius) as a breeding bird in the Žitný ostrov region]. Kárpáti Vadász 3: 19. [In Hungarian]

Levin AS 2000: Problems of saker falcon conservation in Kazakhstan. Falco 16: 8-9.

Levin AS 2008: Conservation problems of the saker falcon in Kazakhstan. Raptors Conservation 12: 48-55.

Levin AS, Kovalenko AV \& Karyakin IV 2010: Saker falcon population trends in south-eastern Kazakhstan. Raptors Conservation 18: 167-174.

Lokcsánszky A 1931: Falco cherrug Gray előfordulása Gömörben. Falco cherrug Gray im Komitate Gömör. Kócsag 4:115-116. [In Hungarian and German]

Losos B, Gulička J, Lellák J \& Pelikán J 1985: Ekologie živočichů [Animal Ecology]. Státní pedagogické nakladatelství, Praha. [In Czech]

Matoušek F 1933: Z okolí Béše na Dunaji [From the surroundings of Béša on the Danube River]. Stráž myslivosti 11: 241-242. [In Czech]

Matoušek F 1956: Hniezdenie a oológia vzácnejších druhov vtákov [Nesting and oology of rare bird species]. Biológia 11(1): 76-87. [In Slovak with Russian and German summaries]

Matoušek B 1962: Faunistický prehl'ad slovenského vtáctva. Čast' II [Faunistical synopsis of Slovakian birds. Part II]. Acta Rev. Natur. Mus. Nat. Slov. Bratislava 8: 3-93. [In Slovak]

Matoušek B 2009: László Erdős - ornitológ, oológ, a zberatel' [László Erdős - ornithologist, oologist and collector]. Zborník Slovenského národného múzea, Bratislava, Prírodné vedy 8: 3-93.

Moseikin V 2000: Saker falcons of the Russian Altai. Falco 16: 5-8.

Mošanský A 1974: Dravce (Falconiformes) východného Slovenska II. Orliaky, včeláre, haje, hadiare, kršiaky a sokoly [Raptors (Falconiformes) of eastern 
Slovakia II. Sea eagles, honey buzzards, kites, snake eagles, ospreys and falcons]. Zborník Východoslovenského múzea v Košiciach, Prírodné vedy 11-14A, 13-14B: 181-224. [In Slovak with German and Russian summaries]

Mošanský A 1991: Avifauna Košíc [Birdlife in Košice]. Zborník Východoslovenského múzea $\mathrm{v}$ Košiciach, Prírodné vedy 31: 49-158.

Nedyalkov N, Levin A, Dixon A \& Boev Z 2014: Diet of saker falcon (Falco cherrug) and eastern imperial eagle (Aquila heliaca) in Central Kazakhstan. Ecologia Balkanica 6 (1): 25-30.

Newton I 2004: The recent declines of farmland bird populations in Britain: an appraisal of causal factors and conservation actions. Ibis 146: 579-600.

Obuch J 2001: Using marked differences from the mean (MDFM) method for evaluation of contingency tables. Buteo 12: 37-46.

Obuch J \& Chavko J 1997: Potrava sokola rároha (Falco cherrug) na juhozápadnom Slovensku [The diet of the saker falcon (Falco cherrug) in SW Slovakia]. Buteo 9: 77-84. [In Slovak with English summary]

Papp G \& Balázs I 2010: Occurrence of saker falcon pairs in an urban environment in Hungary. Heliaca 2010: 113. [In Hungarian with English summary]

Pfeffer J 1994: Competitive advantage through people. Harvard Business School Press, Boston.

Puzović S 2008: Nest occupation and prey grabbing by saker falcon (Falco cherrug) on power lines in Vojvodina Province, Serbia. Archives of Biological Sciences 60: 271-277.

Rahman ML, Purev-ochir G, Batbayar N \& Dixon A 2016: Influence of nest box design on occupancy and breeding success of predatory birds utilizing artificial nests in the Mongolian steppe. Conservation Evidence 13: 21-26.

Rajković D 2016: Distribution, numbers and nest site choice of saker falcon Falco cherrug in Vojvodina Province (N Serbia). Ciconia. 22/23: 39-42.

Snow DW \& Perrins CM 1998: The birds of the Western Palearctic vol. 1: Non-Passerines. Oxford University Press, Oxford.

Shannon CE \& Weaver W 1949: The mathematical theory of communication. University Illinois Press, Urbana.

Šipöcz T 2004: Zber. Databázový program, Verzia 3 [Collection. Database program. Version 3].
Botanical Garden. Comenius University, Blatnica. [in Slovak ]

Soviš B \& Šindár O 1964: Príspevok k nidobiológii a k postembryonálnemu vývoju rároha vel'kého (Falco cherrug) [A contribution to the nidobiology and the postembryonal development of the saker falcon (Falco cherrug)]. Sborník Vysokej školy pol’nohospodárskej v Nitre 10: 70-77. [In Slovak with English summary]

Stretesky P, Mckie R, Lynch M, Long M \& Barrett K 2018: Where have all the falcons gone? Saker falcon (Falco cherrug) exports in a global economy. Global Ecology and Conservation 13: e00372. DOI: 10.1016/j.gecco.2017.e00372.

Štefanová M \& Šálek M 2013: Integrated farming methods and their impact on herb and bird communities of agricultural land - a review. Journal of Central European Agriculture 14 (3): 1158-1170.

Ter Braak CJF \& Šmilauer P 2002: CANOCO Reference manual and CanoDraw for Windows. User's guide. Software for canonical community ordination, ver. 4.5. Microcomputer Power, Ithaca.

Varga J 1969: Výskyt niektorých vzácnejších druhov vtákov v Trenčianskom okrese [Occurrence of some rare birds in the Trenčín district]. Ochrana fauny 3(34): 109-112. [In Slovak]

Vermouzek Z \& Zámečník V 2017: Indikátor ptáků zemědělské krajiny za rok 2017 [Taxonomy of birds in agricultural country in 2017]. Česká společnost ornitologická, Praha.

Wu Y 2011: The diet of saker falcons (Falco cherrug) on the eastern fringe of Gurban Tunggut Desert, China 2011, 8647-8649. In: Piscataway NJ (ed), International Conference on Remote Sensing, Environment and Transportation Engineering. Institute of Electrical and Electronics Engineers, Nanjing. DOI: 10.1109/RSETE.2011.5964190.

Zink R \& Izquierdo D 2012: Erfolgskontrolle Sakerfalken-Nisthilfen Brutsaison 2012. Forschungsinstitut für Wildtierkunde und Ökologie, VetmedUni Vienna.

Zink R, Kovacs FJ, Sonvilla C, Mihók J \& Aberle S 2015: Der Sakerfalke in Mitteleuropa. Erfolgreicher Schutz am westlichen Rand der Verbreitung. 1. Ed. Austrian Power Grid AG, Wien. 


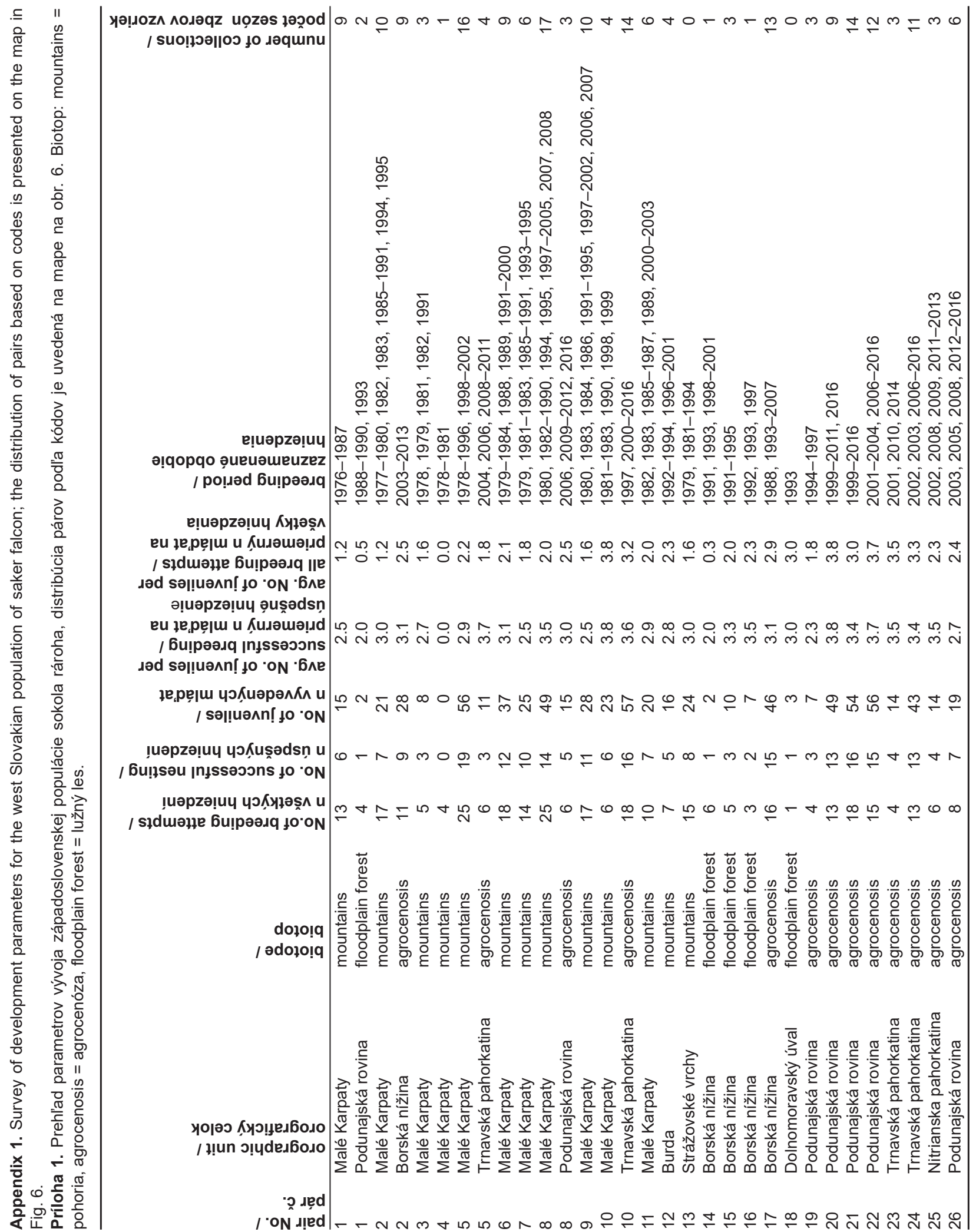




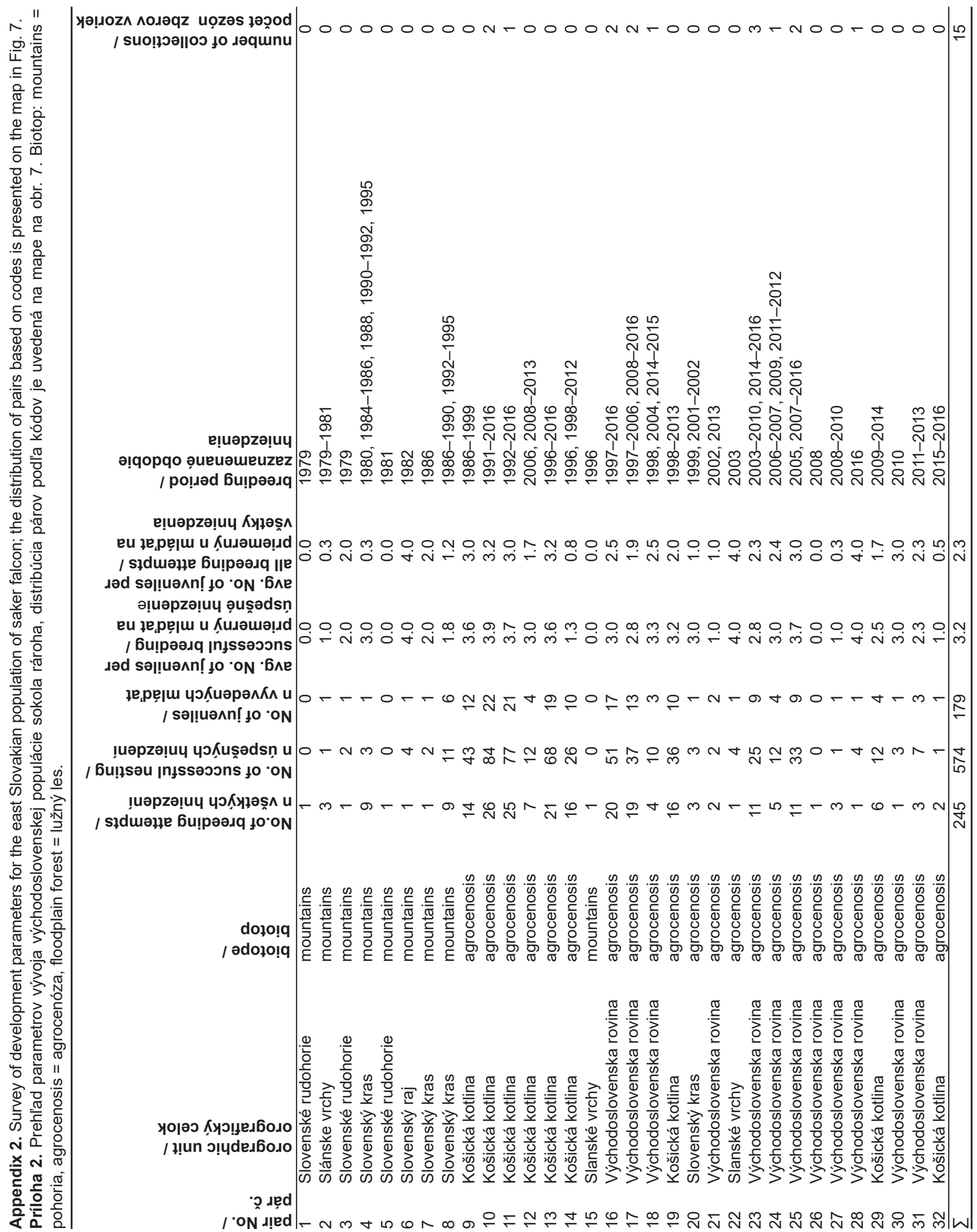




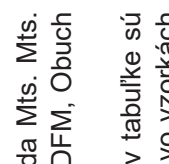

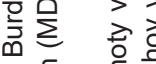

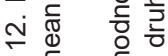

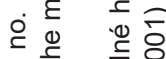

言

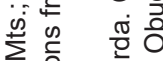

颃产

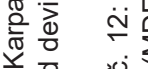

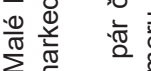

웡

은 는

은

बं $\quad 2 \frac{0}{0}$

N \pm 曲

0 क 은 진

ம)

N $\infty$ क

음

웡

๘) N

$\therefore: \frac{\pi}{\pi}$

ग

으 $\frac{\pi}{\pi}$

ฮั வ

कृ

我它 के

का

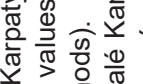

- (1) 宩 $\sum^{\frac{\pi}{2}}$

$\sum$ 일 $\sum_{0} \frac{5}{0}$

๑)

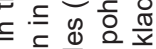

†) 은

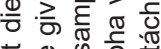

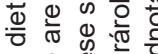

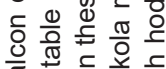

뜐

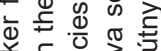

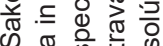

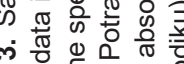

증 정

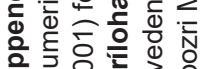

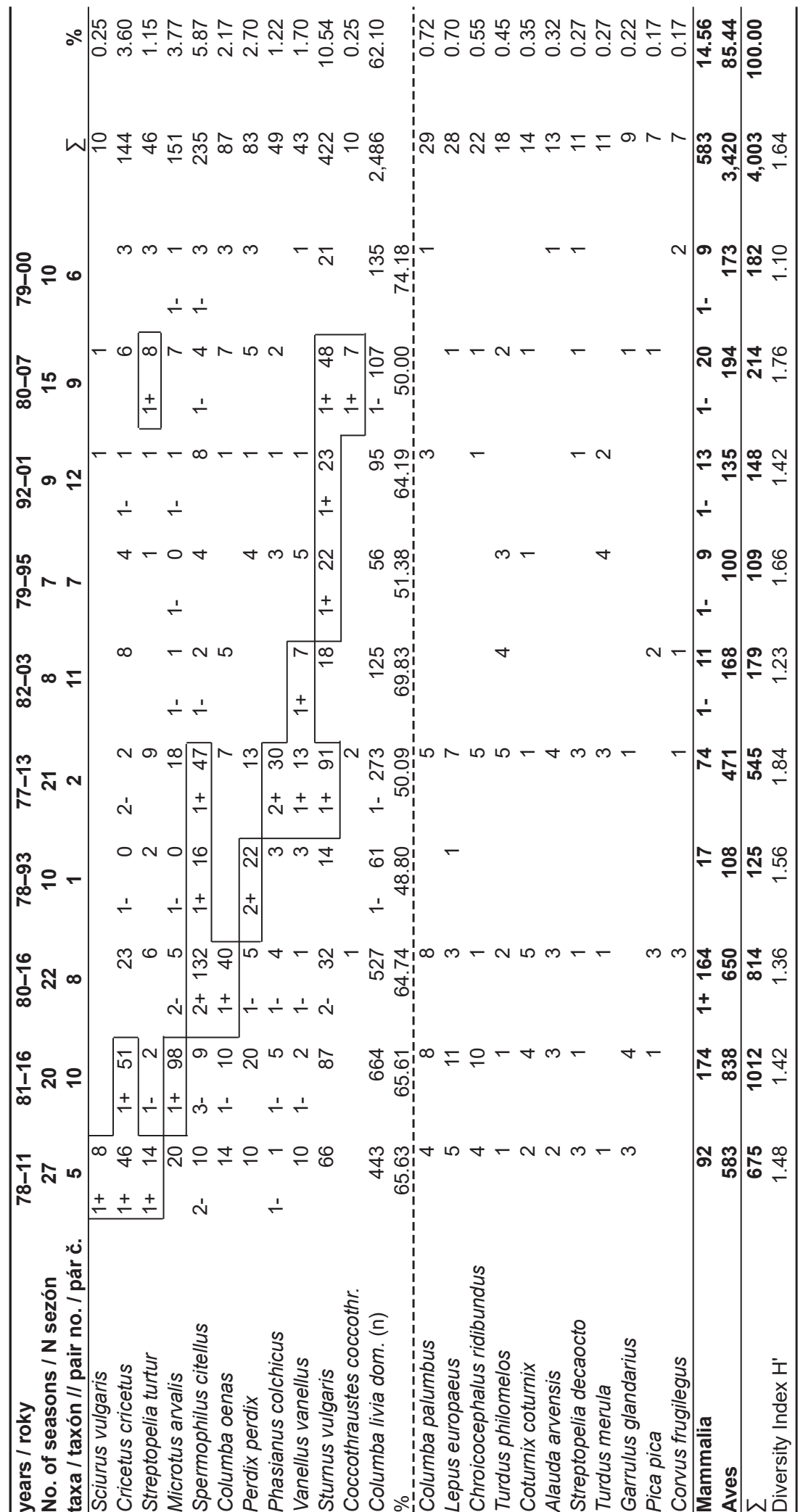




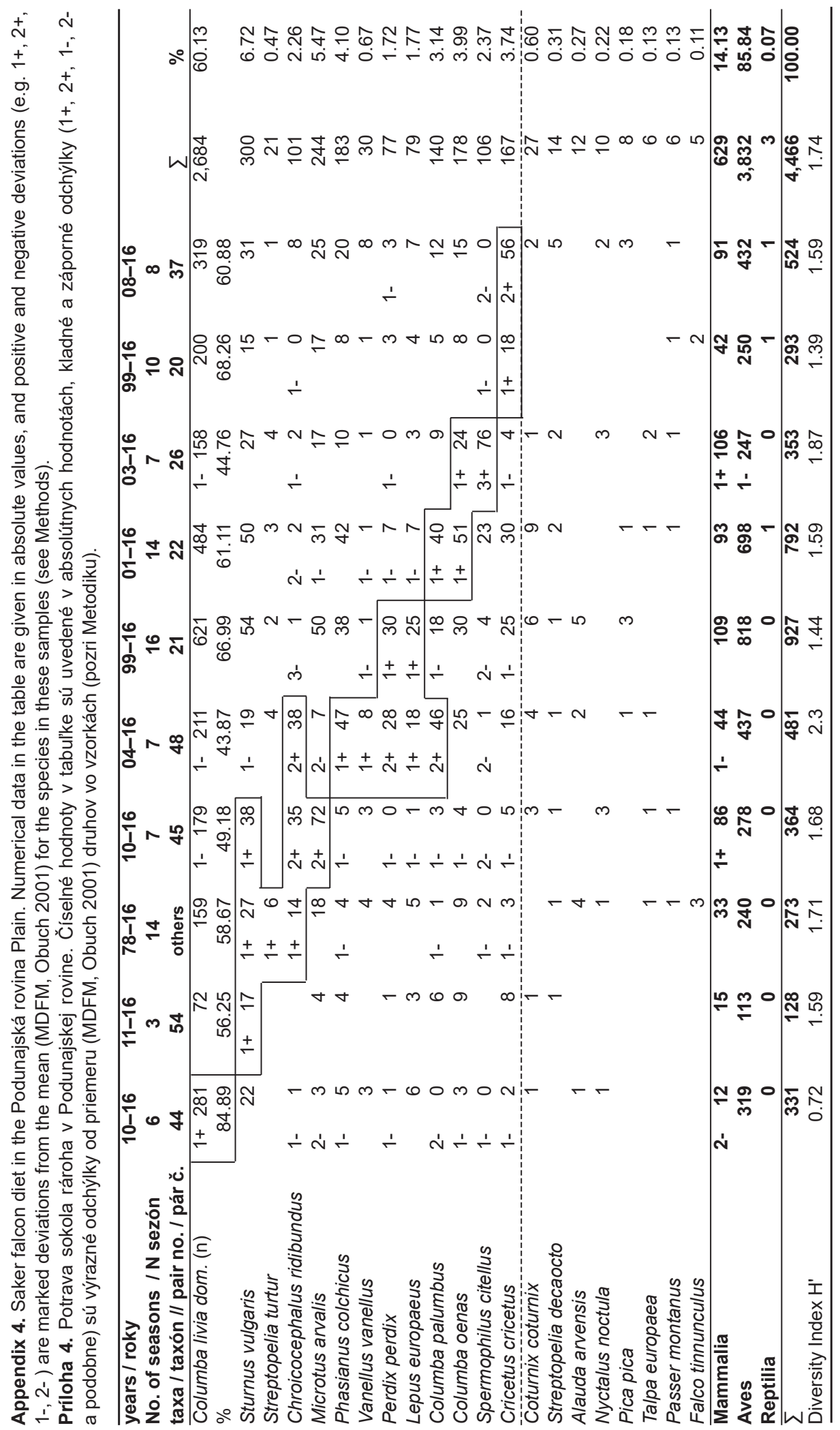




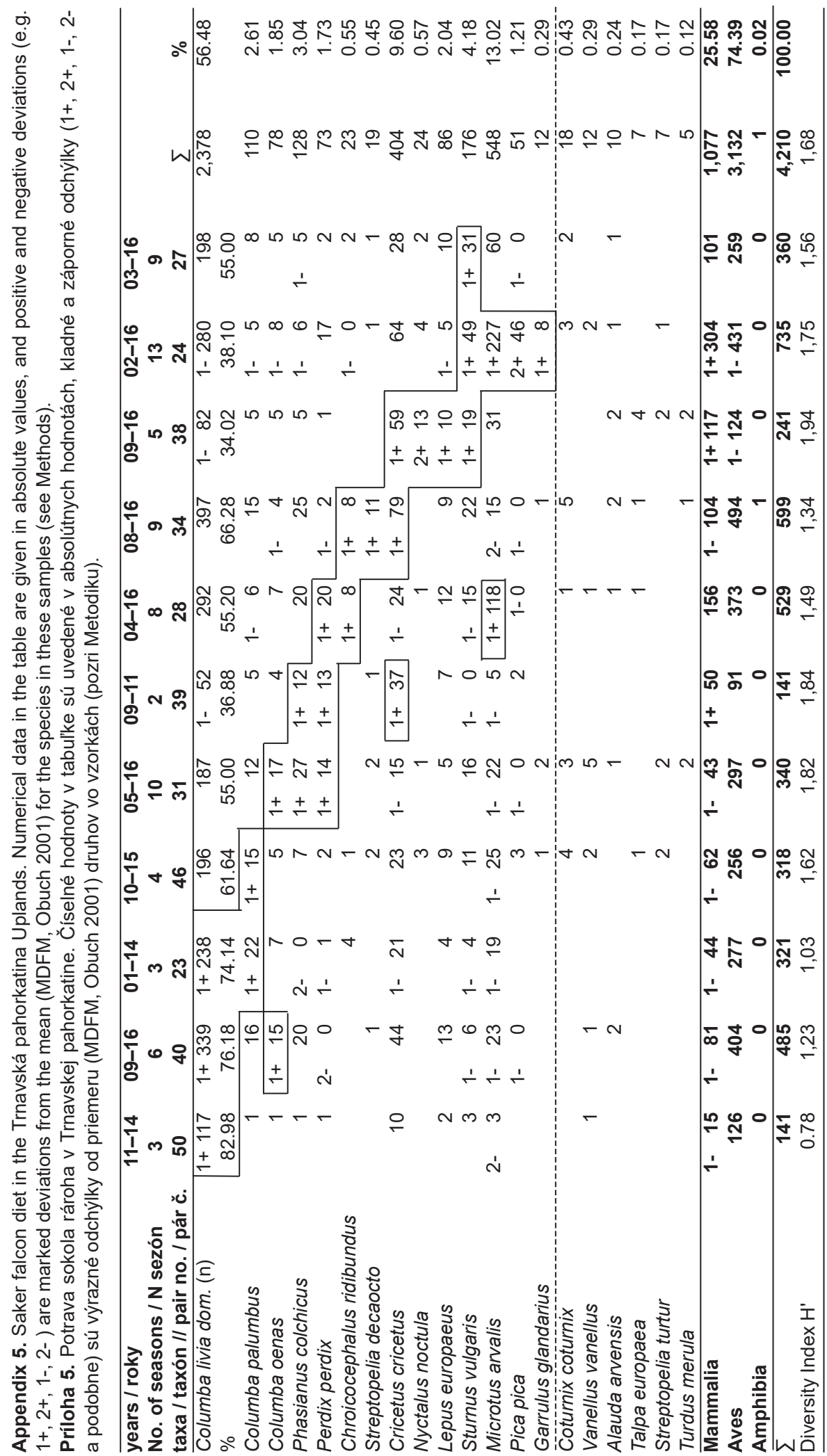




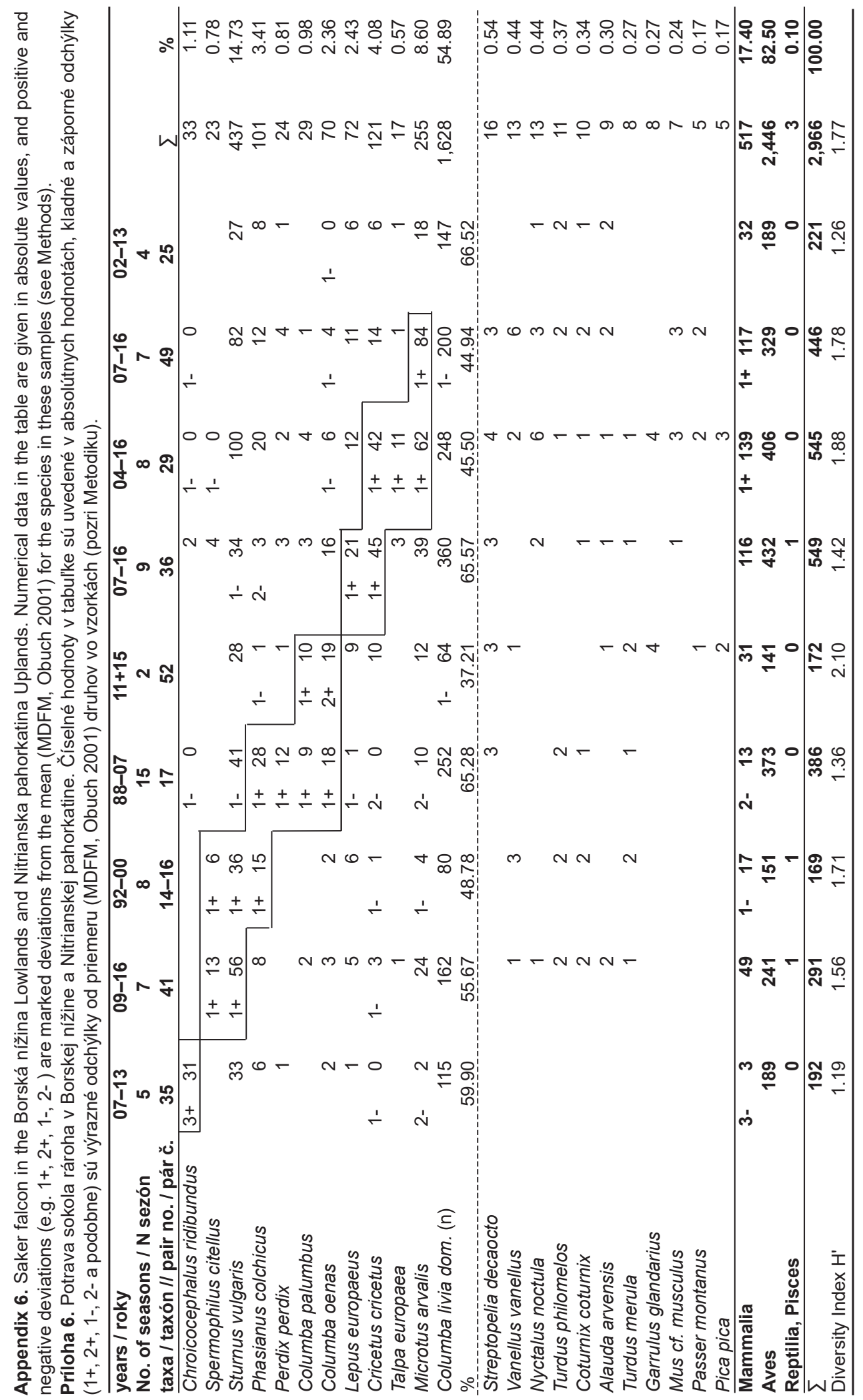


Chavko J, Obuch J, Lipták J, Slobodník R \& Baláž M: Changes in nesting habitat of the saker falcon (Falco cherrug) influenced its diet composition and potentially threatened its population in Slovakia in the years 1976-2016

Appendix 7. Survey of suspected saker falcon nest robberies in western Slovakia 1976-2006.

Príloha 7. Prehl'ad podozrení vykrádania hniezd sokola rároha na západnom Slovensku v 1976 - 2006.

\begin{tabular}{|c|c|c|c|c|}
\hline $\begin{array}{l}\text { year } 1 \\
\text { rok }\end{array}$ & $\begin{array}{l}\text { No. of breeding pairs } / \\
\text { n hniezdiacich párov / }\end{array}$ & $\begin{array}{l}\text { No. of successfull breeding pairs } I \\
\text { úspešne vyhniezdilo } /\end{array}$ & $\begin{array}{c}\text { No. of robbed nests I } \\
\mathrm{n} \text { vykradnutých hniezd }\end{array}$ & $\begin{array}{l}\text { pair no. I } \\
\text { pár č. }\end{array}$ \\
\hline 1976 & 1 & 0 & 1 & 1 \\
\hline 1977 & 2 & 1 & 0 & \\
\hline 1978 & 5 & 2 & 0 & \\
\hline 1979 & 8 & 5 & 1 & 13 \\
\hline 1980 & 7 & 1 & 1 & 1 \\
\hline 1981 & 8 & 6 & 1 & 13 \\
\hline 1982 & 10 & 9 & 0 & \\
\hline 1983 & 11 & 8 & 2 & 6,8 \\
\hline 1984 & 7 & 3 & 1 & 13 \\
\hline 1985 & 8 & 4 & 2 & 1,8 \\
\hline 1986 & 8 & 5 & 1 & 1 \\
\hline 1987 & 7 & 3 & 0 & \\
\hline 1988 & 9 & 5 & 3 & $2,8,13$ \\
\hline 1989 & 9 & 3 & 4 & $1,2,5,13$ \\
\hline 1990 & 7 & 2 & 4 & $1,5,7,13$ \\
\hline 1991 & 9 & 3 & 1 & 13 \\
\hline 1992 & 8 & 7 & 0 & \\
\hline 1993 & 12 & 6 & 1 & 14 \\
\hline 1994 & 12 & 6 & 0 & \\
\hline 1995 & 9 & 7 & 0 & \\
\hline 1996 & 5 & 4 & 0 & \\
\hline 1997 & 9 & 6 & 0 & \\
\hline 1998 & 8 & 7 & 0 & \\
\hline 1999 & 10 & 9 & 0 & \\
\hline 2000 & 12 & 11 & 0 & \\
\hline 2001 & 12 & 8 & 2 & 12,21 \\
\hline 2002 & 11 & 9 & 0 & \\
\hline 2003 & 12 & 10 & 0 & \\
\hline 2004 & 12 & 9 & 1 & 5 \\
\hline 2005 & 13 & 11 & 0 & \\
\hline 2006 & 15 & 11 & 2 & 5,21 \\
\hline$\Sigma$ & 276 & 181 & 28 & \\
\hline
\end{tabular}

